\title{
Determinants of the voltage dependence of $G$ protein modulation within calcium channel $\beta$ subunits
}

\author{
Andriy V. Dresviannikov $\cdot$ Karen M. Page • \\ Jerôme Leroy • Wendy S. Pratt • Annette C. Dolphin
}

Received: 24 April 2008 / Accepted: 17 June 2008 / Published online: 24 July 2008

(C) The Author(s) 2008

\begin{abstract}
Ca}_{\mathrm{V}} \beta$ subunits of voltage-gated calcium channels contain two conserved domains, a $s r c$-homology-3 (SH3) domain and a guanylate kinase-like (GK) domain with an intervening HOOK domain. We have shown in a previous study that, although $\mathrm{G} \beta \gamma$-mediated inhibitory modulation of $\mathrm{Ca}_{\mathrm{V}} 2.2$ channels did not require the interaction of a $\mathrm{Ca}_{\mathrm{V}} \beta$ subunit with the $C a_{v} \alpha 1$ subunit, when such interaction was prevented by a mutation in the $\alpha 1$ subunit, G protein modulation could not be removed by a large depolarization and showed voltage-independent properties (Leroy et al., J Neurosci 25:6984-6996, 2005). In this study, we have investigated the ability of mutant and truncated $\mathrm{Ca}_{\mathrm{V}} \beta$ subunits to support voltage-dependent $\mathrm{G}$ protein modulation in order to determine the minimal domain of the $\mathrm{Ca}_{\mathrm{V}} \beta$ subunit that is required for this process. We have coexpressed the $\mathrm{Ca}_{\mathrm{V}} \beta$ subunit constructs with $\mathrm{Ca}_{\mathrm{V}} 2.2$ and $\alpha_{2} \delta-2$, studied modulation by the activation of the dopamine $\mathrm{D} 2$ receptor, and also examined basal tonic modulation. Our main finding is that the $\mathrm{Ca}_{\mathrm{V}} \beta$ subunit GK domains, from either $\beta 1 \mathrm{~b}$ or $\beta 2$, are sufficient to restore voltage dependence to $\mathrm{G}$ protein modu-
\end{abstract}

Andriy V. Dresviannikov and Karen M. Page contributed equally to this work.

A. V. Dresviannikov $\cdot$ K. M. Page $\cdot$ J. Leroy $\cdot$ W. S. Pratt $\cdot$

A. C. Dolphin $(\triangle)$

Laboratory of Cellular and Molecular Neuroscience,

Department of Neuroscience, Physiology and Pharmacology,

University College London,

Gower Street,

London WC1E 6BT, UK

e-mail: a.dolphin@ucl.ac.uk

Present address:

J. Leroy

INSERM U-769, Faculté de Pharmacie, Université Paris-Sud 11,

5, Rue J.-B. Clément,

92296 Châtenay-Malabry Cedex, France lation. We also found that the removal of the variable HOOK region from $\beta 2$ a promotes tonic voltage-dependent $G$ protein modulation. We propose that the absence of the HOOK region enhances $\mathrm{G} \beta \gamma$ binding affinity, leading to greater tonic modulation by basal levels of $\mathrm{G} \beta \gamma$. This tonic modulation requires the presence of an $\mathrm{SH} 3$ domain, as tonic modulation is not supported by any of the $\mathrm{Ca}_{\mathrm{V}} \beta$ subunit GK domains alone.

Keywords Calcium channel $\cdot$ Beta subunit .

Electrophysiology

\section{Introduction}

Voltage-gated calcium $\left(\mathrm{Ca}_{\mathrm{V}}\right)$ channels play a major role in the physiology of all excitable cells. Three families have been identified, $\mathrm{Ca}_{\mathrm{V}} 1-3$ (for review, see [17]). The highvoltage-activated (HVA) $\mathrm{Ca}_{\mathrm{V}} 1$ and 2 classes are heteromultimers composed of the pore-forming $\alpha 1$ subunit, associated with auxiliary $\mathrm{Ca}_{\mathrm{V}} \beta$ and $\alpha_{2} \delta$ subunits (for review, see [12]). Four $\mathrm{Ca}_{\mathrm{V}} \beta$ subunit genes have been cloned, and these subunits are important for HVA calcium channel function (for review, see [16]), since they promote the expression of functional channels at the plasma membrane and modulate their biophysical properties $[6,8,11,29] . \mathrm{Ca}_{\mathrm{V}} \beta$ subunits bind with high affinity to the $\alpha$-interaction domain (AID) on the I-II loop of $\mathrm{Ca}_{V} 1$ and 2 channels [29], although other $\alpha 1$ subunit interaction sites are also likely to be important in mediating the actions of $\mathrm{Ca}_{\mathrm{V}} \beta$ subunits $[35,40]$.

In a previous study, we investigated the role of $\mathrm{Ca}_{\mathrm{V}} \beta$ subunits in the plasma membrane expression and $\mathrm{G}$ protein modulation of $\mathrm{Ca}_{\mathrm{V}} 2.2$ calcium channels, by mutating the AID tryptophan (W391) in the I-II loop of $\mathrm{Ca}_{\mathrm{V}} 2.2$, and thus disrupting the high-affinity interaction with $\mathrm{Ca}_{\mathrm{V}} \beta$ subunits 
[21]. One conclusion was that the $\mathrm{Ca}_{\mathrm{V}} 2.2 \mathrm{~W} 391 \mathrm{~A}$ mutant channels lost all modulation by $\mathrm{Ca}_{\mathrm{V}} \beta 1 \mathrm{~b}$ and showed strongly reduced expression at the plasma membrane. While they still showed $\mathrm{G}$ protein modulation following the activation of a coexpressed dopamine D2 receptor, this modulation could not be reversed by depolarization. In contrast, for palmitoylated $\mathrm{Ca}_{\mathrm{V}} \beta 2 \mathrm{a}$, only the expression at the plasma membrane was affected when it was coexpressed with the mutant $\mathrm{Ca}_{\mathrm{V}} 2.2 \mathrm{~W} 391 \mathrm{~A}$ channels, while all the biophysical properties of the expressed $\mathrm{Ca}_{\mathrm{V}} 2.2 \mathrm{~W} 391 \mathrm{~A}$ channels remained normally modulated by $\mathrm{Ca}_{v} \beta 2 \mathrm{a}$. Furthermore, they also showed voltagedependent $G$ protein modulation. We concluded that the continuing influence of $\beta 2 \mathrm{a}$ was dependent on its palmitoylation, which increased the local concentration of $\beta 2$ a near the plasma membrane sufficiently to allow lower-affinity interactions to occur between it and the mutant channel $\alpha 1$ subunit, which were effective in modulating the channel properties [21].

$\mathrm{Ca}_{\mathrm{V}} \beta$ subunits were originally predicted by structural modeling to contain a $s r c$-homology-3 (SH3) domain followed by a guanylate kinase-like (GK) domain [18]. The SH3 domain is split with its final (fifth) $\beta$-strand separated from the rest of the domain by an intervening sequence termed the HOOK domain, whose sequence varies between $\mathrm{Ca}_{\mathrm{v}} \beta$ subunits and which is encoded by either a short or an alternative long exon. X-ray crystallographic studies have now produced detailed information on the domain structure [13, 27, 39]. From these studies, it is clear that the fifth $\beta$-strand of the $\mathrm{SH} 3$ domains provides the interaction with the GK domain, being situated after the variable HOOK region, whose structure was not determined (for review, see [31]). The GK domain interacts with the AID motif and has since been shown to be an important determinant of function for the HVA channels [32, 37, 38].
The primary goal of the present study was to determine the minimal domain(s) of $\mathrm{Ca}_{\mathrm{V}} \beta$ subunits that is able to confer voltage dependence on $\mathrm{G}$ protein modulation of $\mathrm{Ca}_{\mathrm{V}} 2.2$ channels.

\section{Materials and methods}

Materials

The cDNAs used in this study were $\mathrm{Ca}_{\mathrm{V}} 2.2$ (D14157), $\mathrm{Ca}_{\mathrm{V}} \beta 1 \mathrm{~b}$ (X61394), $\mathrm{Ca}_{\mathrm{v}} \beta 2 \mathrm{a}$ (M88751), $\alpha_{2} \delta-2$ [2], and dopamine $\mathrm{D}_{2}$ receptor (X17458). When used, the green fluorescent protein (GFP-mut3b, U73901) was used to identify transfected cells. All cDNAs were subcloned into $\mathrm{pMT}_{2}$ vector. Transducin- $\alpha$ was used as described [5].

Construction of truncated $\beta$ subunit domains

We have been guided by the structure in our choice of truncations and deletions in the present study (Fig. 1). In the case of the GK domains, we have used the exon boundary to determine the C-terminal end, since such boundaries often delimit a stable functional domain, and this marks the end of the second conserved domain, as originally identified (for review, see [7]). It was important that the GK domain constructs were stable since previous studies have examined the properties of several GK domain constructs with varying results, regarding their ability to mimic the functions of intact $\mathrm{Ca}_{\mathrm{V}} \beta$ subunits, and it is possible that these constructs have varying stabilities in different cell types [23, 37]. All constructs were made by standard molecular biological techniques and their sequences verified by sequencing both
Fig. 1 Diagram of the main constructs used in the electrophysiological experiments in the present study
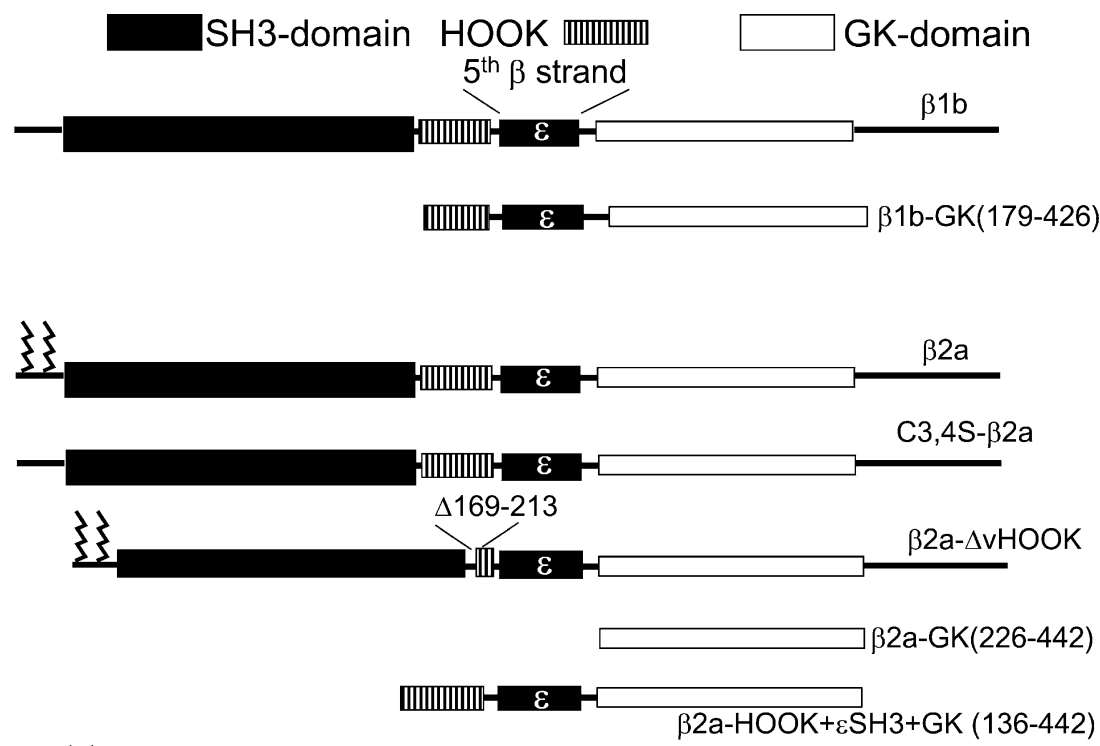

\$?

$\beta 2 \mathrm{a}-\mathrm{SH} 3(1-135)$ 
strands. The truncated constructs used for electrophysiology (with their amino acid residues) were $\beta 2 \mathrm{a}-\Delta$-vHOOK $(\Delta 169$ 213), $\beta 2 \mathrm{a}-\mathrm{SH} 3$ (1-135), $\beta 2 \mathrm{a}-(\mathrm{SH} 3+\mathrm{HOOK}+\varepsilon \mathrm{SH} 3)(1-225)$, $\beta 2 \mathrm{a}-\mathrm{GK}(226-442), \beta 2 \mathrm{a}-(\mathrm{HOOK}+\varepsilon \mathrm{SH} 3+\mathrm{GK})(136-442)$, $\beta 1 b-G K(230-426)$, and $\beta 1 b-(H O O K+\varepsilon S H 3+G K)(179-426)$.

\section{Yeast two-hybrid assays}

Assays were carried out using the MATCHMAKER GAL4 two-hybrid kit (Clontech). Fragments of $\mathrm{Ca}_{\mathrm{v}} \beta 2 \mathrm{a}$ (amino acids 5-442, 5-134, 5-224, 135-442, 214-442, or 225-442), the $\mathrm{Ca}_{\mathrm{V}} 2.2 \mathrm{I}-\mathrm{II}$ loop (360-483), and $\mathrm{Ca}_{\mathrm{V}} \beta 1 \mathrm{~b}$ were generated by polymerase chain reaction and subcloned in-frame into the vectors pACT2 and pAS2-1. Plasmids were cotransformed into the yeast strain Y190 and transformants were selected by plating onto minimal selective dropout (SD) -Leu, -Trp agar. Protein interactions were identified by restreaking colonies onto SD -Leu, -Trp plates and carrying out colony-lift $\beta$-galactosidase assays according to the supplied protocol.

Cell culture, heterologous expression, and whole cell recording

The tsA-201 cells were cultured in a medium consisting of DMEM, $10 \%$ fetal bovine serum, $2 \mathrm{mM}$ glutamine, $100 \mathrm{IU} / \mathrm{ml}$ penicillin, and $100 \mu \mathrm{g} / \mathrm{ml}$ streptomycin. The cDNAs (all at $1 \mu \mathrm{g} / \mu \mathrm{l}$ ) for $\mathrm{Ca}_{V} \alpha 1$ subunits, $\mathrm{Ca}_{V} \beta, \alpha_{2} \delta-2$, and GFP (when used as a reporter of transfected cells) were mixed in a ratio of 3:2:2:0.4. The cells were transfected using Fugene 6 (Roche Diagnostics, Lewes, UK; DNA/Fugene 6 ratio of $2 \mu \mathrm{g}$ in $3 \mu \mathrm{l})$. The tsA-201 cells were replated at low density on 35-mm tissue culture dishes on the day of recording. Whole-cell patch-clamp recordings were performed at room temperature $\left(22-24^{\circ} \mathrm{C}\right)$. Only fluorescent cells expressing GFP were used for recording. The single cells were voltageclamped using an Axopatch 200B patch-clamp amplifier (Molecular Devices). The electrode potential was adjusted to give zero current between pipette and external solution before the cells were attached. The cell capacitance varied from 10 to $40 \mathrm{pF}$. Patch pipettes were filled with a solution containing (in mM) 140 Cs-aspartate, 5 EGTA, $2 \mathrm{MgCl}_{2}, 0.1$ $\mathrm{CaCl}_{2}, 2 \mathrm{~K}_{2}$ ATP, 10 HEPES, titrated to $\mathrm{pH} 7.2$ with $\mathrm{CsOH}$ (310 mOsm) with a resistance of 2-4 M $\Omega$. The external solution contained (in $\mathrm{mM}$ ) 150 tetraethylammonium bromide, $3 \mathrm{KCl}, 1.0 \mathrm{NaHCO}_{3}, 1.0 \mathrm{MgCl}_{2}, 10$ HEPES, 4 glucose, 10 $\mathrm{BaCl}_{2}, \mathrm{pH}$ adjusted to 7.4 with Tris-Base (320 mOsm). The pipette and cell capacitance as well as the series resistance were compensated by $80 \%$. Leak and residual capacitance current were subtracted using a $\mathrm{P} / 4$ protocol. All experiments in which quinpirole was applied were carried out in small volume disposable glass chambers (300-500 $\mu$ l volume) with a perfusion rate of 200-300 $\mu 1 / \mathrm{s}$, which were used once only, excluding the possibility that tonic modulation was due to prior quinpirole exposure. Quinpirole was made up as a 10-mM stock solution, and aliquots were diluted as necessary and used once only.

Data were filtered at $2 \mathrm{kHz}$ and digitized at $5-10 \mathrm{kHz}$. The holding potential was $-100 \mathrm{mV}$, and pulses were delivered every $10 \mathrm{~s}$. Test pulses were normally $40 \mathrm{~ms}$ in duration, and in the three pulses, protocol $P_{1}$ and $P_{2}$ were separated by at least $150 \mathrm{~ms}$, and $P_{2}$ was preceded by a $50-\mathrm{ms}$ prepulse to $+120 \mathrm{mV}$. Activation properties were determined from tail current measurements, as previously described [21]. Steadystate inactivation properties were measured by applying a 5 to 20 -s pulse (depending on the inactivation properties of the currents) from -120 to $+20 \mathrm{mV}$ in $10-\mathrm{mV}$ increments, followed by $11 \mathrm{~ms}$ repolarization to $-100 \mathrm{mV}$ before the $100-\mathrm{ms}$ test pulse to $+20 \mathrm{mV}$.

\section{Data analysis and curve fitting}

Current amplitude was measured $10 \mathrm{~ms}$ after the onset of the test pulse, and the average over a 2-ms period was calculated and used for subsequent analysis. The current densityvoltage $(I-V)$ relationships were fitted with a modified Boltzmann equation as follows: $I=G_{\max } \times\left(V-V_{\text {rev }}\right) /$ $\left(1+\exp \left(-\left(V-V_{50, \text { act }}\right) / k\right)\right)$ where $I$ is the current density (in $\mathrm{pA} / \mathrm{pF}$ ), $G_{\max }$ is the maximum conductance (in $\mathrm{nS} / \mathrm{pF}$ ), $V_{\text {rev }}$ is the reversal potential, $V_{50 \text {, act }}$ is the midpoint voltage for current activation, and $k$ is the slope factor. Activation and steady-state inactivation data were fitted with a single Boltzmann equation of the form: $I=I_{\max }\left(\left(A_{1}-A_{2}\right) /[1+\right.$ $\left.\exp \left(\left(V-V_{50, \text { inact }}\right) / k\right)\right]+A_{2}$. where $I_{\max }$ is the maximal current and $V_{50 \text {, inact }}$ is the half-maximal voltage for current inactivation. For the steady-state inactivation, $A_{1}$ and $A_{2}$ represent the total and noninactivating current, respectively. Analysis was performed using Pclamp7 and Origin 7.

Data are expressed as the mean \pm SEM of the number of replicates, $n$. Error bars indicate the standard errors of multiple determinations. Statistical significance was analyzed using Student's paired or unpaired $t$ test or by ANOVA with Bonferroni's post hoc test, if multiple comparisons were made.

\section{Results}

The isolated GK domains of $\mathrm{Ca}_{\mathrm{V}} \beta 1 \mathrm{~b}$ and $\beta 2 \mathrm{a}$ support voltage-dependent $\mathrm{G}$ protein modulation

In a previous study, we used a $\mathrm{Ca}_{\mathrm{V}} 2.2$ construct with a mutation in the I-II loop (W391A), such that it did not show high-affinity interaction with $\mathrm{Ca}_{\mathrm{V}} \beta$ subunits, and observed a lack of voltage dependence of the quinpirole-mediated inhibition in the presence of $\beta 1 \mathrm{~b}$ [21]. From that study, we concluded that the interaction of $\mathrm{Ca}_{\mathrm{V}} \beta$ with the I-II linker 
was necessary for voltage-dependent $\mathrm{G}$ protein modulation. However, it is possible that this interaction with the I-II linker is not sufficient in itself, but is required to bring another region of the $\mathrm{Ca}_{\mathrm{V}} \beta$ subunits into proximity with the channel. In particular, we found that for $\beta 2 \mathrm{a}$, voltagedependent $\mathrm{G}$ protein modulation was still present, despite the W391A mutation in the I-II linker. Therefore, there remained a question as to whether the palmitoylation of $\beta 2 \mathrm{a}$ resulted in a sufficiently high concentration of $\mathrm{Ca}_{\mathrm{V}} \beta$ subunit being present near to the I-II linker of the channel, such that there was high occupancy by $\beta 2 \mathrm{a}$ of the mutated I-II linker, despite a very low-affinity interaction or whether the residual interaction was with another domain of $\beta 2 \mathrm{a}$ on another part of the channel [21].

In order to examine which domain of $\mathrm{Ca}_{\mathrm{V}} \beta$ was necessary to promote the voltage dependence of $\mathrm{G}$ protein modulation, we compared the ability of full-length $\beta 1 \mathrm{~b}$ or $\beta 2 \mathrm{a}$ and their isolated GK domains to support voltage-dependent $G$ protein modulation. The constructs used are shown in Fig. 1. We coexpressed all the $\beta$ subunit constructs with $\mathrm{Ca}_{\mathrm{V}} 2.2$ and $\alpha_{2} \delta$-2. For coexpression with full-length $\mathrm{Ca}_{\mathrm{V}} \beta 1 \mathrm{~b}$, the peak $I_{\mathrm{Ba}}$ was $-158.2 \pm 25.7 \mathrm{pA} / \mathrm{pF}$ at $+20 \mathrm{mV}(n=35)$. For comparison, in the absence of any $\mathrm{Ca}_{\mathrm{V}} \beta$ subunit, the peak $I_{\mathrm{Ba}}$ at $+30 \mathrm{mV}$ was $-8.3 \pm 1.0 \mathrm{pA} / \mathrm{pF}(\mathrm{n}=9)$, in experiments performed over the same time period. For $\mathrm{Ca}_{\mathrm{v}} 2.2 / \alpha_{2} \delta-2 / \beta 1 \mathrm{~b}$ currents, application of the dopamine D2 receptor agonist quinpirole $(100 \mathrm{nM})$ produced maximally $63.7 \pm 6.6 \%$ inhibition at $+10 \mathrm{mV}$ (Fig. 2a,b). This inhibition showed a strong voltage dependence, as the $P_{2} / P_{1}$ ratio was $2.97 \pm 0.23$ at $+10 \mathrm{mV}$ (Fig. 2a,c). This is an example of complete voltage dependence, since full reversal of a $64 \%$ inhibition predicts a $P_{2} / P_{1}$ ratio of 2.8 . In the absence of any coexpressed $\beta$ subunit, quinpirole $(100 \mathrm{nM})$ application still produced a substantial effect, resulting in $44 \pm 13 \%$ inhibition at $+10 \mathrm{mV}$ (Fig. 2a,b). However, the voltage dependence of this inhibition was very low, the $P_{2} / P_{1}$ ratio being $1.3 \pm 0.11$ at $+10 \mathrm{mV}$ (Fig. 2a,c; $P<0.0001$ compared to $\beta 1 \mathrm{~b}$ ), as we described previously for $\mathrm{Ca}_{\mathrm{V}} 2.2 \mathrm{~W} 391 \mathrm{~A}$, which did not interact with $\beta 1 \mathrm{~b}$ [21].

We then utilized one of the truncated $\mathrm{Ca}_{\mathrm{V}} \beta 1 \mathrm{~b}$ subunit constructs described previously [32] to examine which domain(s) of $\mathrm{Ca}_{\mathrm{v}} \beta 1 \mathrm{~b}$ were required to promote the voltage dependence of $\mathrm{G}$ protein modulation. We found that a $\beta 1 \mathrm{~b}$ GK domain construct ( $\beta 1 b-H O O K+\varepsilon S H 3+$ GK $(179-426)$ ), containing both the HOOK region and the fifth $\beta$-strand, coexpressed with $\mathrm{Ca}_{\mathrm{v}} 2.2 / \alpha_{2} \delta-2$, enhanced calcium channel currents to a smaller extent than full-length $\beta 1 \mathrm{~b}$ subunit, the peak current at $+20 \mathrm{mV}$ being $-79.8 \pm 16.2 \mathrm{pA} / \mathrm{pF}(n=7)$, as described previously [32]. However, quinpirole $(100 \mathrm{nM})$ produced $67.5 \pm 6.9 \%$ inhibition of $I_{\mathrm{Ba}}$ at $+10 \mathrm{mV}$, and this inhibition could be relieved by a depolarizing prepulse to $+120 \mathrm{mV}$ (Fig. 2a,b). The $P_{2} / P_{1}$ ratio was greater than that in the absence of any $\beta$ subunit at all potentials, being $2.06 \pm$
0.15 at $+10 \mathrm{mV}$ (Fig. 2a,c; $P<0.001$ compared to no $\beta$ subunit). It is important to note that for all $\beta 1 \mathrm{~b}$ constructs, the basal facilitation prior to the application of quinpirole was not significantly different from unity (Fig. 2d). This result indicates that the interaction of the $\mathrm{Ca}_{\mathrm{V}} 2.2 \mathrm{I}-\mathrm{II}$ linker with the GK domain of the $\mathrm{Ca}_{\mathrm{V}} \beta 1 \mathrm{~b}$ subunit is sufficient to promote voltage dependence of $\mathrm{G}$ protein modulation, and the SH3 domain is not required.

For $\mathrm{Ca}_{\mathrm{v}} 2.2 / \alpha_{2} \delta-2$ together with full-length $\beta 2 \mathrm{a}$, the peak $I_{\mathrm{Ba}}$ was $-145.9 \mathrm{pA} / \mathrm{pF}$ at $+20 \mathrm{mV}$ (Table 1). Quinpirole $(100 \mathrm{nM})$ inhibited these currents to a smaller extent, producing maximally $38.7 \pm 4.9 \%$ inhibition at $+10 \mathrm{mV}$ (Fig. 3a,b; $P=0.0042$ compared to $\beta 1 \mathrm{~b}$ ). This inhibition showed a $P_{2} / P_{1}$ ratio of $1.88 \pm 0.19$ at $+10 \mathrm{mV}$ (Fig. 3a,c). The low $P_{2} / P_{1}$ ratio was to be expected, in view of the small inhibition by quinpirole.

Based on our previous findings [21], it is likely that there is increased interaction between the $\beta 2$ a subunit and $\mathrm{Ca}_{\mathrm{V}} 2.2$, as a result of palmitoylation elevating its effective concentration at the plasma membrane and increasing its availability to interact with the channel. We found that removal of the palmitoylation motif on $\beta 2 \mathrm{a}(\mathrm{C} 3,4 \mathrm{~S}-\beta 2 \mathrm{a})$

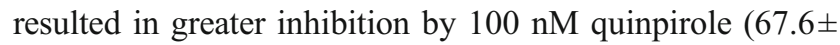
$7.5 \%$ inhibition at $+10 \mathrm{mV}$, Fig. 3a,b; $P=0.0047$ compared to $\beta 2 \mathrm{a}$ ), and correspondingly increased the $P_{2} / P_{1}$ ratio to $2.93 \pm 0.67$ at $+10 \mathrm{mV}$ (Fig. 3b,c).

Similar to our finding for the $\beta 1 b-\mathrm{HOOK}+\varepsilon S H 3+\mathrm{GK}$ construct, we found that $\beta 2 \mathrm{a}-\mathrm{HOOK}+\varepsilon \mathrm{SH} 3+\mathrm{GK}(136-442)$ supported voltage-dependent $G$ protein modulation. This construct, coexpressed with $\mathrm{Ca}_{\mathrm{v}} 2.2 / \alpha_{2} \delta-2$, enhanced calcium channel currents to a smaller extent than full-length $\beta 2 \mathrm{a}$ subunit, the peak $I_{\mathrm{Ba}}$ being $-63.2 \mathrm{pA} / \mathrm{pF}$ at $+20 \mathrm{mV}$ (Table 1). However, the inhibition by $100 \mathrm{nM}$ quinpirole was $56.0 \pm 7.2 \%$ at $+10 \mathrm{mV}$ (Fig. $3 \mathrm{~b}$ ), and the $P_{2} / P_{1}$ ratio was $2.04 \pm 0.48$ at $+10 \mathrm{mV}$ (Fig. 3c).

Similar results were obtained for a minimal GK domain of $\beta 2 \mathrm{a}, \beta 2-\mathrm{GK}$ (226-442), coexpressed with $\mathrm{Ca}_{\mathrm{v}} 2.2 / \alpha_{2} \delta-2$ where the peak current density at $+20 \mathrm{mV}$ was $-79.9 \mathrm{pA} / \mathrm{pF}$ (Table 1). Although the interaction of this GK domain with the I-II linker of $\mathrm{Ca}_{\mathrm{V}} 2.2$ was not confirmed in our yeast two-hybrid results (see Fig. 6), this may be a result of misfolding in the yeast system, as in tsA-201 cells, the peak $I_{\mathrm{Ba}}$ was significantly greater in the presence of $\beta 2 \mathrm{a}-\mathrm{GK}$ (226-442) than in the absence of any $\beta$ subunit $(P<0.05$, Table 1). Furthermore, the steady-state inactivation was also significantly hyperpolarized compared to the absence of any $\beta$ subunit $(P<0.01$, Table 1$)$, to a similar extent to full-length $\beta 1 \mathrm{~b}$ [21] or $\mathrm{C} 3,4 \mathrm{~S}-\beta 2 \mathrm{a}$ (Table 1) [32]. Both these results indicate that the calcium channel currents are influenced by $\beta 2 \mathrm{a}-\mathrm{GK}(226-442)$ interacting with the I-II linker of $\mathrm{Ca}_{\mathrm{v}}$ 2.2. Moreover, quinpirole $(100 \mathrm{nM})$ produced $62.0 \pm 6.7 \%$ inhibition at $+10 \mathrm{mV}$, and the inhibition could be relieved by a depolarizing prepulse (Fig. 3a,b). The 

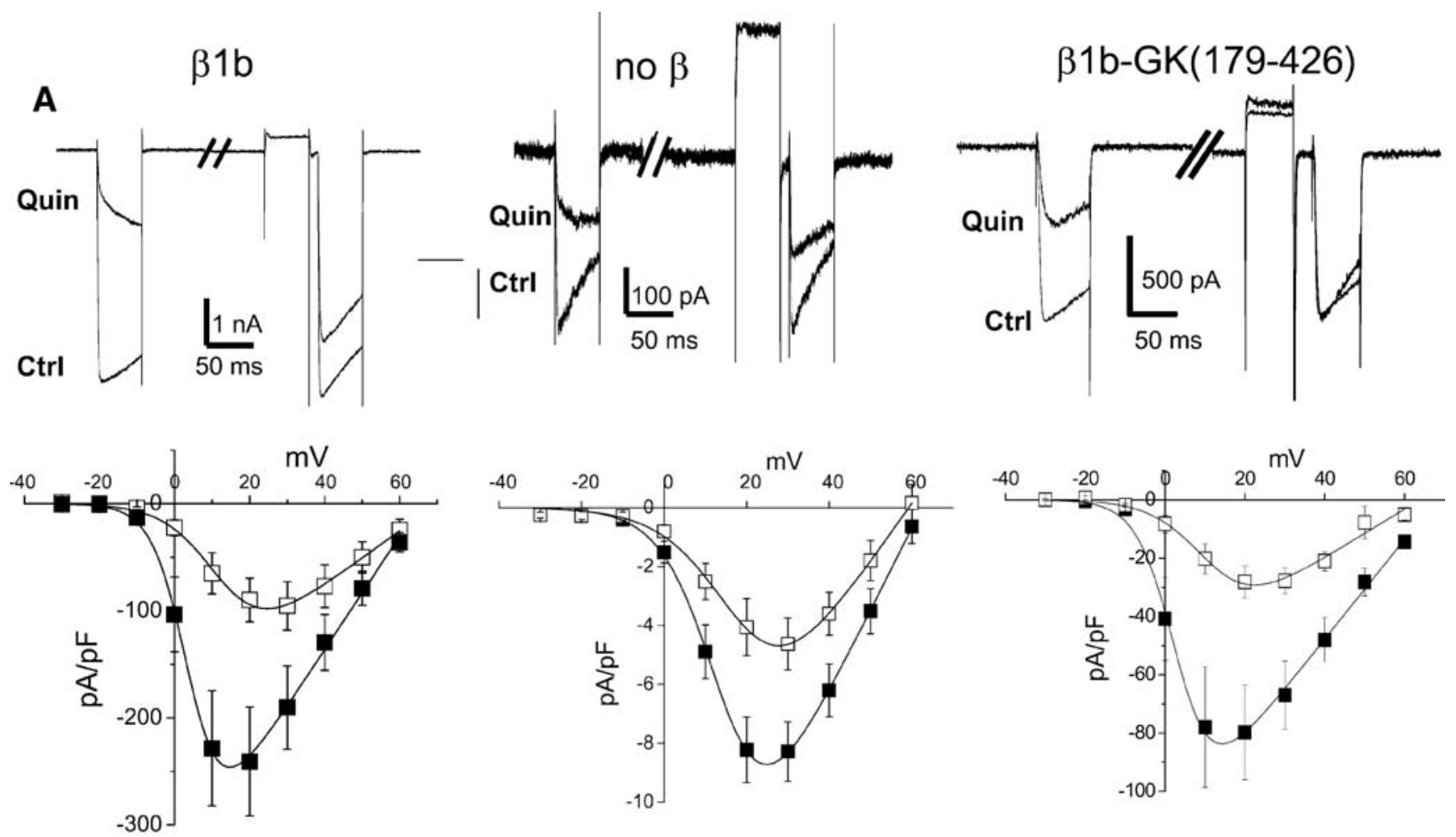

B

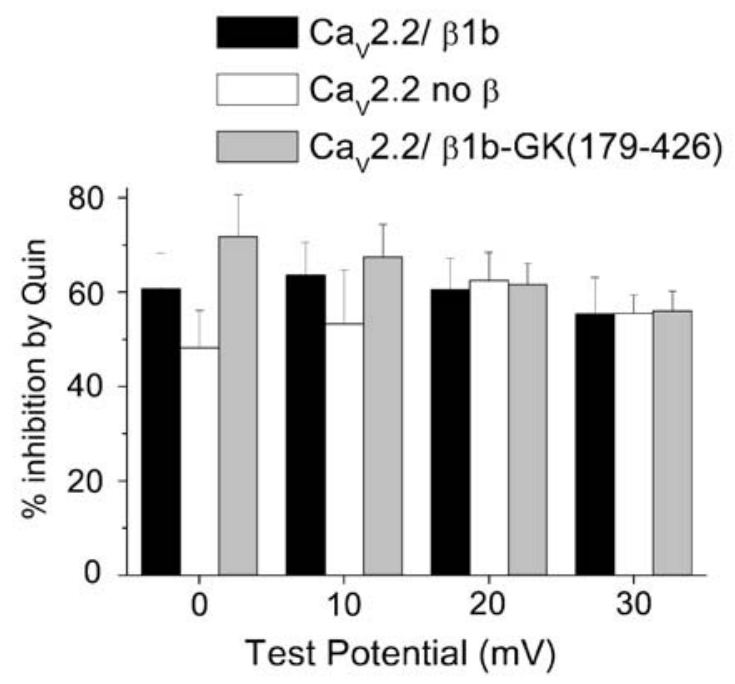

Fig. 2 GK domain of $\beta 1 \mathrm{~b}$ restores voltage dependence to $\mathrm{G}$ protein modulation. a Upper panel example traces showing inhibition of $\mathrm{Ca}_{\mathrm{V}} 2.2$ currents (Ctrl) by quinpirole (Quin, $100 \mathrm{nM}$ ) for $\mathrm{Ca}_{\mathrm{V}} 2.2 / \alpha_{2} \delta-2$ coexpressed with $\beta 1 \mathrm{~b}$ (left), without $\beta$ (center), and with $\beta 1 \mathrm{~b}-\mathrm{GK}$ (179-426) (right). Traces are shown for $40 \mathrm{~ms}$ depolarizations to $+10 \mathrm{mV}$ before and after a depolarizing prepulse to $+100 \mathrm{mV}$. Lower panel current-voltage relationships for the same conditions, prior to (filled squares) and during quinpirole application (open squares) $(n=$

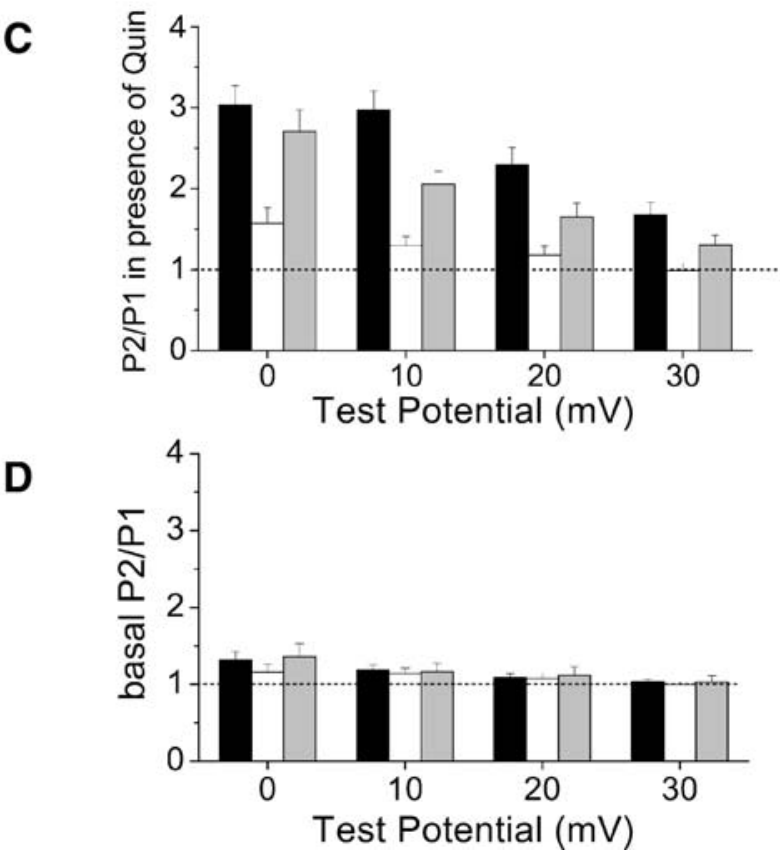

10, 9, and 7, respectively). b Percentage inhibition by quinpirole between 0 and $+30 \mathrm{mV}$ for the three conditions depicted in a. Black bars $+\beta 1 \mathrm{~b}(n=10)$, white bars no $\beta(n=7)$, and gray bars $+\beta 1 \mathrm{~b}-\mathrm{GK}$ $(179-426)(n=7)$. c Facilitation $\left(P_{2} / P_{1}\right)$ ratio between 0 and $+30 \mathrm{mV}$ in the presence of quinpirole for the same experiments as in $\mathbf{b}$. The dotted line indicates a $P_{2} / P_{1}$ ratio of 1 , i.e., no facilitation. d Basal facilitation $\left(P_{2} / P_{1}\right)$ ratio between +10 and $+30 \mathrm{mV}$ for the same experiments as in $\mathbf{b}$. The dotted line indicates a $P_{2} / P_{1}$ ratio of 1 
Table 1 The effect of various $C a_{V} \beta$ subunit constructs on biophysical parameters of $\mathrm{Ca}_{\mathrm{V}} 2.2 / \alpha_{2} \delta-2$ calcium channel currents expressed in tsA-201 cells

\begin{tabular}{|c|c|c|c|}
\hline$\beta$ species & Peak $I_{\mathrm{Ba}}, \mathrm{pA} / \mathrm{pF}(n)$ & Voltage for peak $I_{\mathrm{Ba}}(\mathrm{mV})$ & Steady-state inactivation $V_{50}$ inact, $\mathrm{mV}(n)$ \\
\hline No $\beta$ & $-8.3 \pm 1.0(9)$ & +30 & $-25.4 \pm 7.5(3)$ \\
\hline$\beta 2 \mathrm{a}$ & $-145.9 \pm 34.9(14)^{* *}$ & +20 & $+0.47 \pm 2.16(6)^{* *}$ \\
\hline $\mathrm{C} 3,4 \mathrm{~S}-\beta 2 \mathrm{a}$ & $-96.6 \pm 12.0(21)^{*}$ & +20 & $-47.6 \pm 1.4(3)^{* * \dagger \dagger}$ \\
\hline B2-GK (226-442) & $-79.9 \pm 23.9(17)^{*}$ & +20 & $-54.8 \pm 3.0(5)^{* * \dagger \dagger}$ \\
\hline ß2a-GK (136-442) & $-63.2 \pm 12.7(18)^{\dagger}$ & +20 & $-45.5 \pm 3.0(5)^{* * \dagger \dagger}$ \\
\hline$\beta 2 \mathrm{a}-\Delta \mathrm{vHOOK}$ & $-131.3 \pm 26.8(16)^{* *}$ & +20 & $-14.2 \pm 6.0(6)$ \\
\hline $\mathrm{C} 3,4 \mathrm{~S}-\beta 2 \mathrm{a}-\Delta \mathrm{vHOOK}$ & $-101.4 \pm 15.4(20)^{*}$ & +20 & $-46.0 \pm 1.8(5)^{* * \dagger \dagger}$ \\
\hline$\beta 2-\mathrm{SH} 3(1-135)+\beta 2-\mathrm{GK}(226-442)$ & $-28.0 \pm 11.1(9)^{\dagger \dagger}$ & +20 & $-57.3 \pm 1.4(4)^{* * \dagger \dagger}$ \\
\hline
\end{tabular}

Statistical significances (one-way analysis of variance and Bonferroni's post hoc test) were determined for differences compared to $\mathrm{Ca}_{\mathrm{V}} 2.2$ expressed without any $\beta$ subunit or compared to $\mathrm{Ca}_{\mathrm{V}} 2.2$ expressed with wild-type $\beta 2$ a subunit

${ }^{*} P<0.05$ and $* * P<0.01, \mathrm{Ca}_{\mathrm{V}} 2.2$ expressed without any $\beta$ subunit; ${ }^{\dagger} P<0.05$ and ${ }^{\dagger \dagger} P<0.01, \mathrm{Ca}_{\mathrm{V}} 2.2$ expressed with wild-type $\beta 2 \mathrm{a}$ subunit

$P_{2} / P_{1}$ ratio was $2.73 \pm 0.37$ at $+10 \mathrm{mV}$ (Fig. 3a,c). This result confirms that the interaction of the $\mathrm{Ca}_{\mathrm{V}} 2.2 \mathrm{I}-\mathrm{II}$ linker with the GK domain of any $\mathrm{Ca}_{\mathrm{V}} \beta$ subunit is sufficient to promote voltage dependence of $\mathrm{G}$ protein modulation. For all the $\mathrm{Ca}_{\mathrm{V}} \beta 2$ constructs depicted in Fig. 3c, their basal $P_{2} /$ $P_{1}$ values were between 1 and 1.5 , indicating little basal facilitation was present (Fig. 3d).

Investigation of the roles of the $\mathrm{Ca}_{\mathrm{V}} \beta \mathrm{SH} 3$ and $\mathrm{HOOK}$ domains in voltage-dependent $\mathrm{G}$ protein modulation

In order to examine whether the SH3 domain and the HOOK domain of $\beta 2$ a played a role in the reduced $G$ protein modulation shown by $\beta 2 \mathrm{a}$, we examined the effect of a $\beta 2 \mathrm{a}$ construct in which the SH3 domain and the GK domain are present, but which is missing amino acids 169-213, comprising the variable HOOK domain $(\beta 2 \mathrm{a}-\delta \mathrm{vHOOK})[32]$. The basic properties of $I_{\mathrm{Ba}}$ resulting from the coexpression of $\mathrm{Ca}_{\mathrm{V}} 2.2 / \alpha_{2} \delta-2 / \beta 2 \mathrm{a}-\Delta \mathrm{vHOOK}$ are given in Table 1 . For $\beta 2 \mathrm{a}-$ $\Delta \mathrm{vHOOK}$, the amount of inhibition by quinpirole was $39.9 \pm$ $6.7 \%$ at $+10 \mathrm{mV}$, not significantly different from $\beta 2 \mathrm{a}$ itself (Fig. 4a,b). Evidence from our previous study [32] indicated that this construct remains palmitoylatable, such that the concentration at the plasma membrane and thus the occupancy by this construct of the I-II linker is likely to remain high. However, unlike full-length $\beta 2 \mathrm{a}$, the $P_{2} / P_{1}$ ratio was also high, being $2.85 \pm 0.56$ at $+10 \mathrm{mV}$ (Fig. 4c).

A potential reason for the discrepancy between the low percentage of inhibition and the high $P_{2} / P_{1}$ ratio for $\beta 2 \mathrm{a}$ $\triangle \mathrm{vHOOK}$, compared to full-length $\beta 2 \mathrm{a}$, is that currents in the presence of this construct were also observed to show strong basal facilitation. This is likely to account for the high $P_{2} / P_{1}$ ratio during quinpirole application, as the depolarizing prepulse also removes tonic facilitation. Prior to any agonist application, the $P_{2} / P_{1}$ ratio in the presence of $\beta 2 \mathrm{a}-\Delta \mathrm{vHOOK}$ was $2.34 \pm 0.22$ at $+10 \mathrm{mV}$ (Fig. 5a,b). For comparison, wildtype $\beta 2 \mathrm{a}$ showed only a small degree of basal facilitation,
$P_{2} / P_{1}$ under control conditions being $1.43 \pm 0.13$ at $+10 \mathrm{mV}$ (Fig. $3 \mathrm{~d}, P<0.05$ compared to $\beta 2 \mathrm{a}-\Delta \mathrm{vHOOK}$ ), and $\mathrm{C} 3,4 \mathrm{~S}$ $\beta 2 \mathrm{a}-\mathrm{GK}$ also showed no tonic facilitation (Fig. 3d). Furthermore, $\beta 2-G K(226-442)$ showed no basal facilitation in the absence of agonist, the $P_{2} / P_{1}$ ratio being $1.2 \pm 0.17$ at $+10 \mathrm{mV}$ (Figs. 3d and 5a,b). For the proximally extended GK domain $\beta 2 \mathrm{a}-\mathrm{GK}$ (136-442), there was also no significant basal facilitation, $P_{2} / P_{1}$ in the absence of agonist being $1.5 \pm 0.17$ at $+10 \mathrm{mV}$ (Fig. 3d).

This basal facilitation in the presence of $\beta 2 \mathrm{a}-\Delta \mathrm{vHOOK}$ was due to tonic $\mathrm{G}$ protein modulation since it could be removed by coexpression of transducin- $\alpha$, which acts as a sink for free $\mathrm{G} \beta \gamma$ subunits. The basal $P_{2} / P_{1}$ ratio in the presence of transducin- $\alpha$ was $1.14 \pm 0.05$ at $+10 \mathrm{mV}$ (Fig. 5b). Basal facilitation was also absent when guanosine 5'-O-(2-thiodiphosphate) (GDP- $\beta \mathrm{S}, 200 \mu \mathrm{M})$ was included in the patch pipette (data not shown). This concentration of GDP- $\beta S$ also blocked quinpirole-mediated inhibition (data not shown).

In order to examine whether the presence of basal facilitation was favored by the palmitoylation of the $\beta 2 \mathrm{a}$ $\Delta \mathrm{vHOOK}$, we also examined the properties of $\mathrm{C} 3,4 \mathrm{~S}-\beta 2 \mathrm{a}-$ $\Delta v H O O K$. The basic properties of currents in the presence of this construct are given in Table 1. Quinpirole-mediated inhibition was much higher than for the palmitoylatable construct, being $79.2 \pm 3.1 \%$ at $+10 \mathrm{mV}$, similar to that obtained for $\mathrm{C} 3,4 \mathrm{~S}-\beta 2 \mathrm{a}$ (Fig. 4a,b). The $P_{2} / P_{1}$ ratio was correspondingly high, being $3.22 \pm 0.74$ at $+10 \mathrm{mV}$ (Fig. 4a,c). However, this construct showed no basal facilitation, the $P_{2} / P_{1}$ ratio prior to agonist application being $1.02 \pm 0.05$ at $+10 \mathrm{mV}$ (Fig. 5b).

In the presence of $\beta 2 \mathrm{a}-\Delta \mathrm{vHOOK}$, the time constant for dissociation $\left(\tau_{\text {dissoc }}\right)$ of tonically bound $\mathrm{G} \beta \gamma$ at $+120 \mathrm{mV}$ was $33.6 \pm 6.5 \mathrm{~ms}(n=10$, Fig. $5 \mathrm{c})$. In contrast, for the small amount of tonic facilitation shown by wild-type $\beta 2 \mathrm{a}$, the $\tau_{\text {dissoc }}$ at $+120 \mathrm{mV}$ was $21.3 \pm 4.5 \mathrm{~ms}(n=10$, Fig. $5 \mathrm{c})$, indicating a higher dissociation rate of $\mathrm{G} \beta \gamma$ from wild-type $\beta 2 \mathrm{a}$ at $+120 \mathrm{mV}$ of $46.9 \mathrm{~s}^{-1}$ compared to $29.7 \mathrm{~s}^{-1}$ for $\beta 2 \mathrm{a}-$ $\Delta v H O O K$, although the difference did not reach statistical 

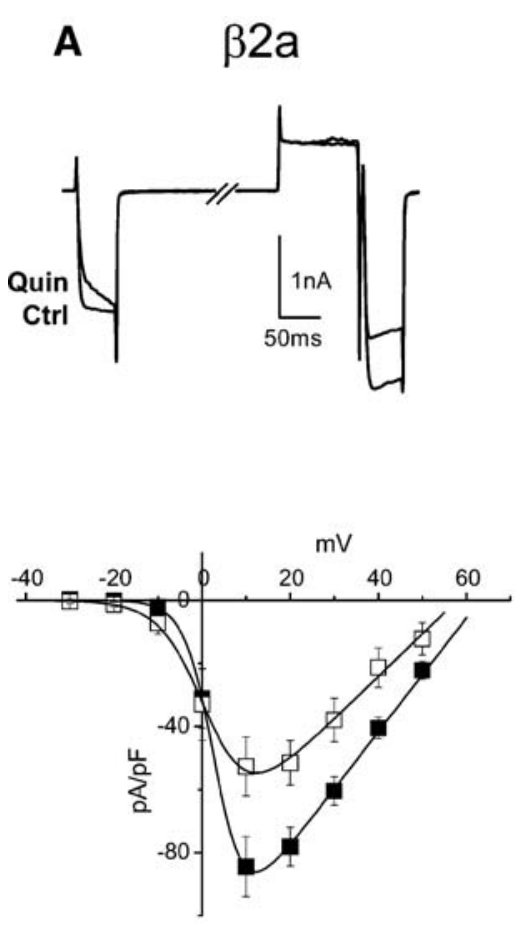

B

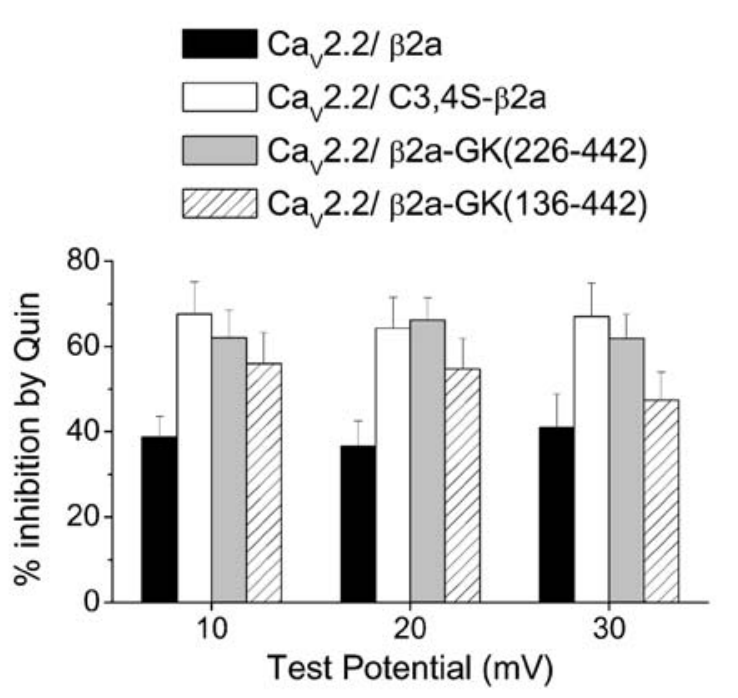

Fig. 3 GK domains of $\beta 2$ a support voltage-dependent $G$ protein modulation. a Upper panel example traces showing inhibition of $\mathrm{Ca}_{\mathrm{V}} 2.2$ currents $(C t r l)$ by quinpirole (Quin, $\left.100 \mathrm{nM}\right)$ for $\mathrm{Ca}_{\mathrm{V}} 2.2 / \alpha_{2} \delta-2$ coexpressed with $\beta 2 \mathrm{a}$ (left), $\mathrm{C} 3,4 \mathrm{~S}-\beta 2 \mathrm{a}$ (center), and with $\beta 2 \mathrm{a}-\mathrm{GK}$ (226-442) (right). Traces are shown for $40 \mathrm{~ms}$ depolarizations to $+10 \mathrm{mV}$ before and immediately after a depolarizing prepulse to $+120 \mathrm{mV}$. Lower panel current-voltage relationships for the same conditions prior to (filled squares) and during quinpirole application (open squares), ( $n=6,6$, and 7, respectively). b Percentage inhibition $\beta 2 a$ GK (226-442)
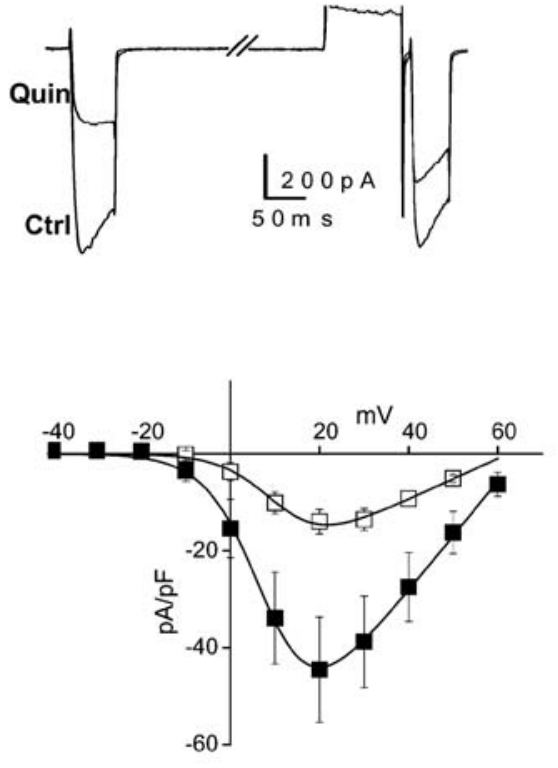

C

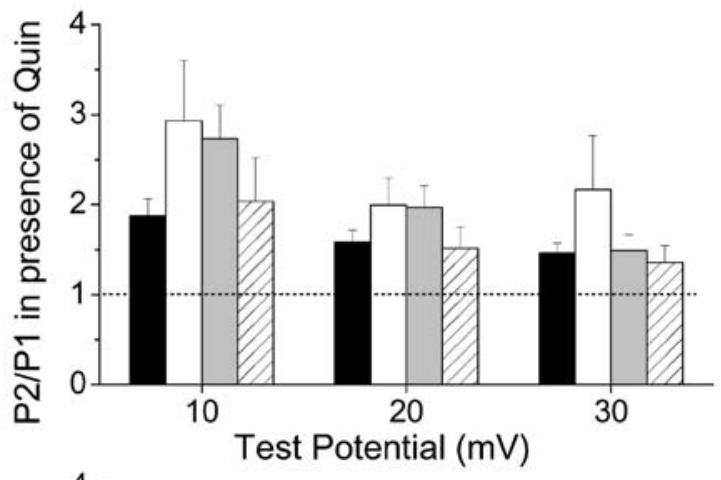

D

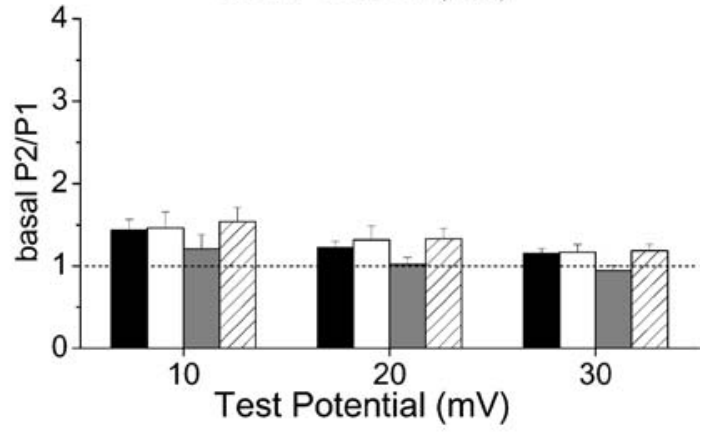

by quinpirole between +10 and $+30 \mathrm{mV}$ for the three conditions depicted in a and the additional GK domain construct $\beta 2 \mathrm{a}-\mathrm{GK}$ (136442) $\left(n=9,7,11\right.$, and 11 , respectively). c Facilitation $\left(P_{2} / P_{1}\right)$ ratio between +10 and $+30 \mathrm{mV}$ in the presence of quinpirole for the three conditions depicted in a and $\beta 2 \mathrm{a}-\mathrm{GK}(136-442)(n=7,8,9$, and 6, respectively). The dotted line indicates a $P_{2} / P_{1}$ ratio of 1 . d Basal facilitation $\left(P_{2} / P_{1}\right)$ ratio between +10 and $+30 \mathrm{mV}$ for the three conditions depicted in a and $\beta 2 \mathrm{a}-\mathrm{GK}(136-442)(n=7,9,10$, and 9, respectively). The dotted line indicates a $P_{2} / P_{1}$ ratio of 1 
A

$\beta 2 \mathrm{a} \triangle \mathrm{vHOOK}$
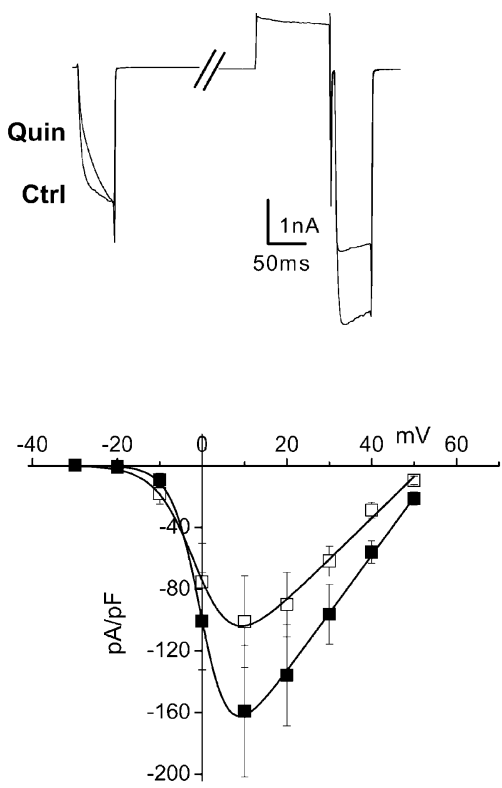

B

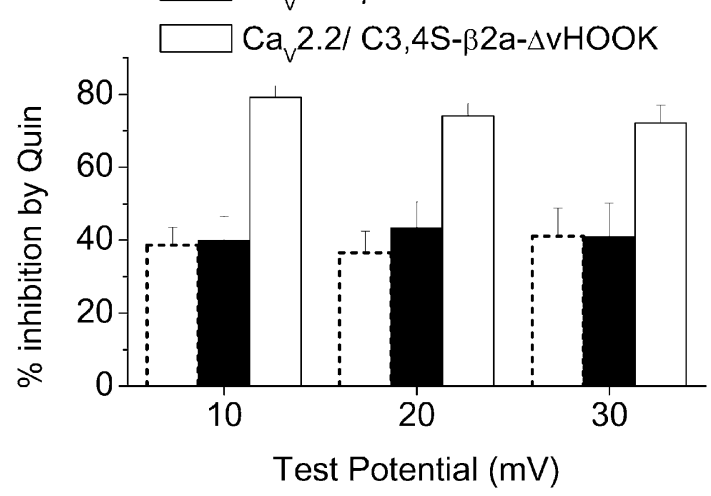

Fig. 4 The determinants for voltage-dependent $\mathrm{G}$ protein modulation and facilitation in the presence of $\beta 2 \mathrm{a}$ constructs. a Upper panel example traces showing inhibition of $\mathrm{Ca}_{\mathrm{V}} 2.2$ currents $(C t r l)$ by quinpirole (Quin, $100 \mathrm{nM}$ ) for $\mathrm{Ca}_{\mathrm{v}} 2.2 / \alpha_{2} \delta-2$ coexpressed with $\beta 2 \mathrm{a}-$ $\Delta \mathrm{vHOOK}($ left $)$ and $\mathrm{C} 3,4 \mathrm{~S}-\beta 2 \mathrm{a}-\Delta \mathrm{vHOOK}($ right). Traces are shown for $40 \mathrm{~ms}$ depolarizations to $+10 \mathrm{mV}$ before and after a depolarizing prepulse to $+120 \mathrm{mV}$. Lower panel current-voltage relationships for the same conditions prior to (filled squares) and during quinpirole

significance. The time constant for rebinding of $G \beta \gamma$ at $-100 \mathrm{mV}$ to wild-type $\beta 2 \mathrm{a}$ was $247.7 \pm 25.9 \mathrm{~ms}$, and for $\beta 2 \mathrm{a}-\Delta \mathrm{vHOOK}$, it was $296.4 \pm 24.2 \mathrm{~ms}$ (Fig. $5 \mathrm{~d}, P>0.05$ ).

Assuming a basal $\mathrm{G} \beta \gamma$ concentration of $50 \mathrm{nM}$, as estimated previously [34], we can utilize the tonic $P_{2} / P_{1}$ ratio and the rate of $\mathrm{G} \beta \gamma$ rebinding after a depolarizing prepulse to determine the $K_{\mathrm{D}}$ for $\mathrm{G} \beta \gamma$ at $-100 \mathrm{mV}$, as described previously [34]. For $\mathrm{Ca}_{\mathrm{V}} 2.2$ coexpressed with wild-type $\beta 2 \mathrm{a}$, the $k_{\text {off }}$ for $\mathrm{G} \beta \gamma$ was calculated to be $2.83 \mathrm{~s}^{-1}$ and the
C3,4S $\beta 2 \mathrm{a} \triangle \mathrm{vHOOK}$
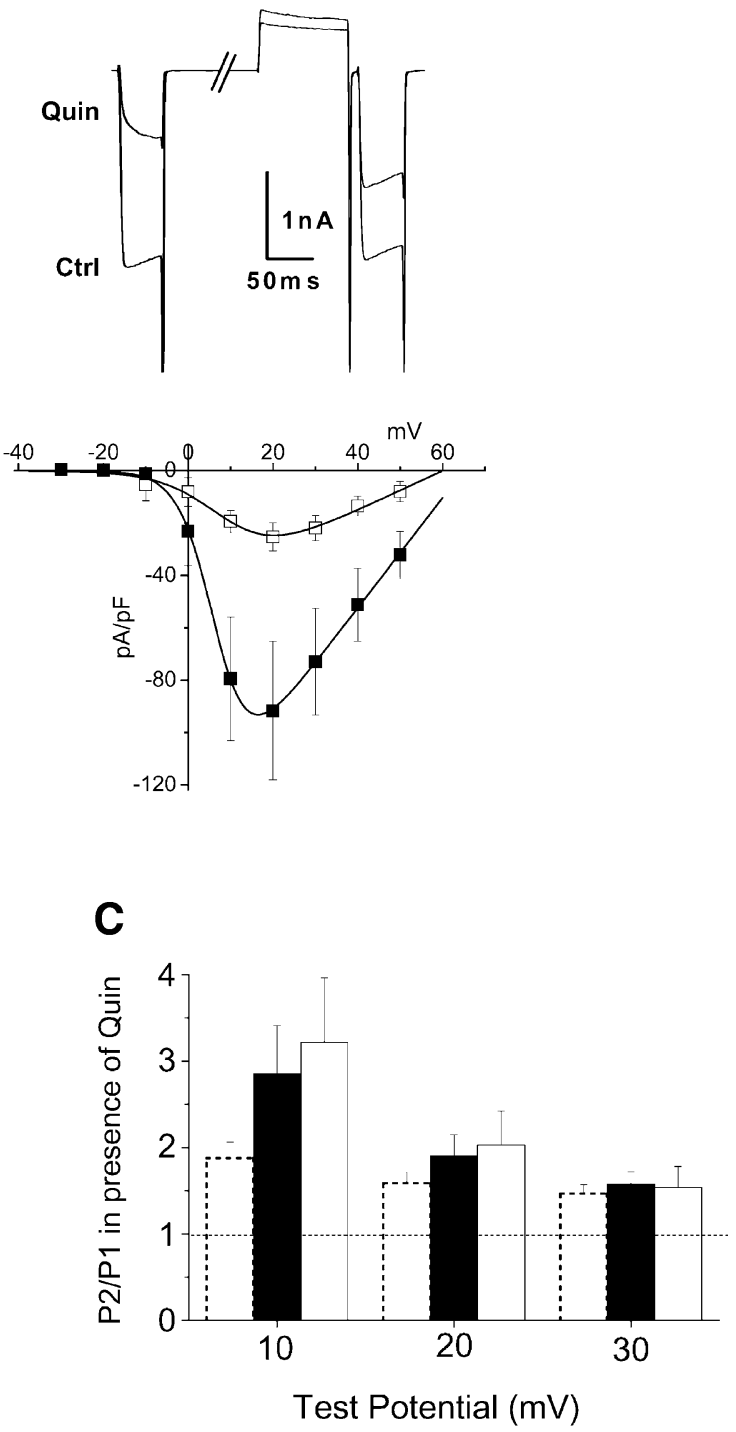

application (open squares) ( $n=6$ for both). b Percentage inhibition by quinpirole between +10 and $+30 \mathrm{mV}$ for the two conditions depicted in $\mathbf{a}(n=10$ and 8 , respectively). Data for $\beta 2$ a from Fig. 3 is included for comparison (dashed bar). c Facilitation $\left(P_{2} / P_{1}\right)$ ratio between +10 and $+30 \mathrm{mV}$ in the presence of quinpirole for the two conditions depicted in a ( $n=9$ and 8 , respectively). Data for $\beta 2$ a from Fig. 3 is included for comparison (dashed bar). The dotted line indicates a $P_{2} / P_{1}$ ratio of 1

$k_{\text {on }}$ was $24.2 \mu \mathrm{M}^{-1} \mathrm{~s}^{-1}$, leading to a $K_{\mathrm{D}}$ for $\mathrm{G} \beta \gamma$ interaction with the channel of $116.9 \mathrm{nM}$. We estimated the in vitro affinity of the interaction of the isolated $\mathrm{Ca}_{\mathrm{V}} 2.2 \mathrm{I}-\mathrm{II}$ linker and $\mathrm{G} \beta \gamma$ to be $62 \mathrm{nM}$ [3]. This is likely to be modulated in the intact channel, particularly by the presence of the $\mathrm{Ca}_{\mathrm{V}} \beta$ subunit. In contrast, for $\mathrm{Ca}_{\mathrm{v}} 2.2$ with $\beta 2 \mathrm{a}-\Delta \mathrm{vHOOK}$, the $k_{\text {off }}$ was $1.44 \mathrm{~s}^{-1}$ and the calculated $k_{\mathrm{on}}$ was $38.6 \mu \mathrm{M}^{-1} \mathrm{~s}^{-1}$, leading to a much higher affinity for $\mathrm{G} \beta \gamma$, the $K_{\mathrm{D}}$ being $37.3 \mathrm{nM}$. It is worth noting that, as expected, the $k_{\text {off }}$ was 
A
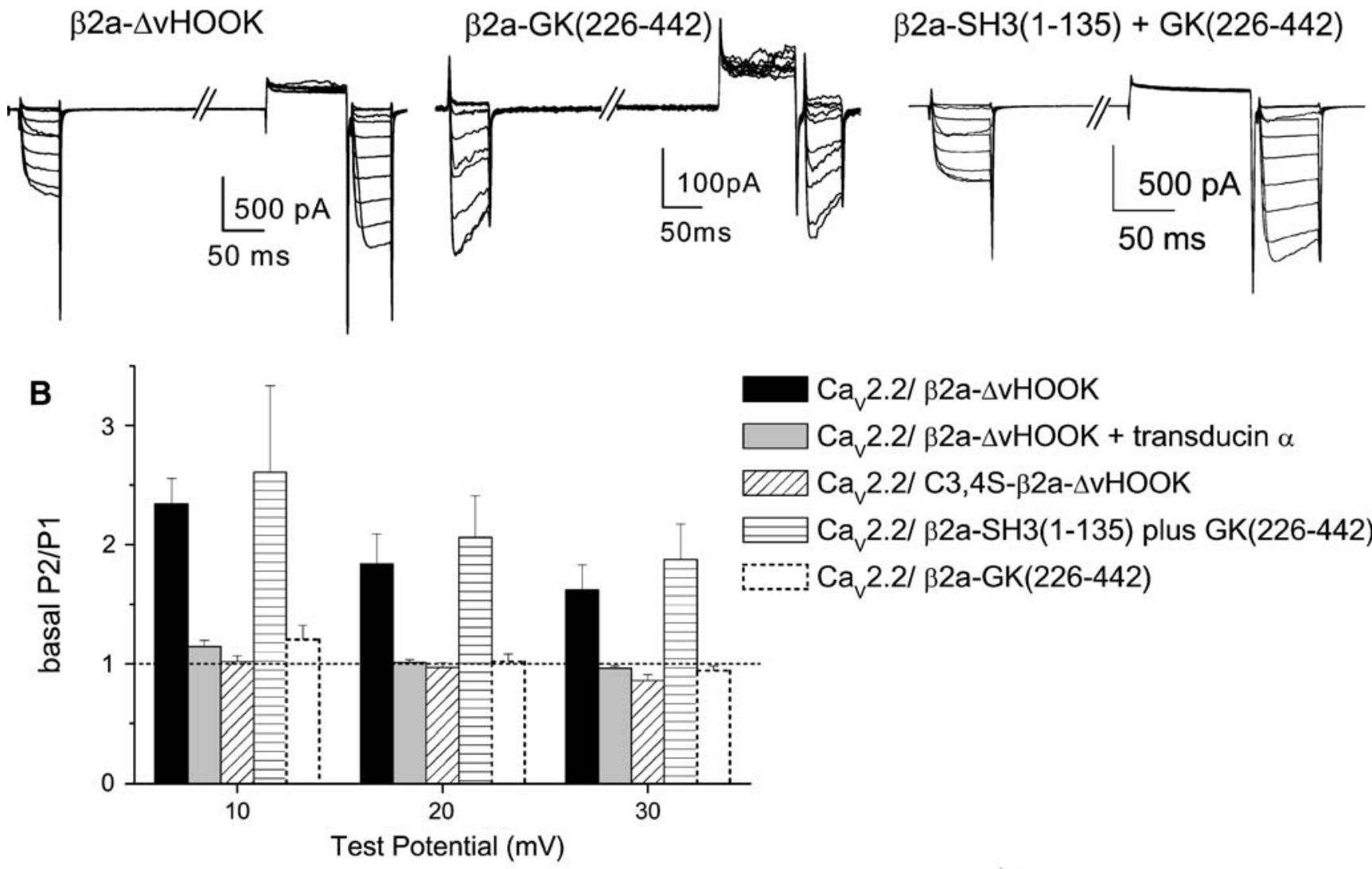

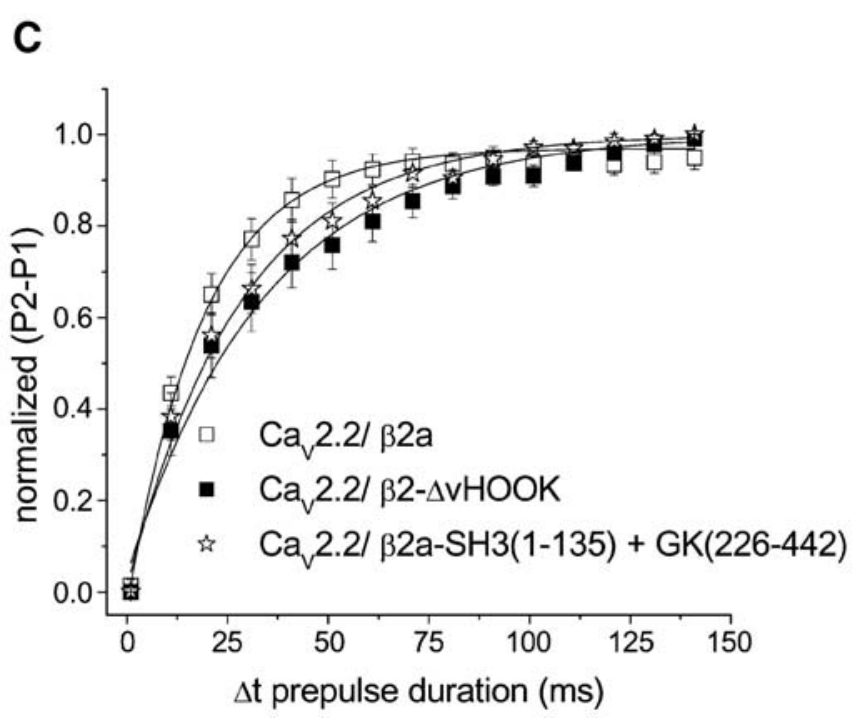

Fig. 5 The determinants for basal facilitation in the presence of $\beta 2 \mathrm{a}$ constructs. a Example traces showing basal facilitation of $\mathrm{Ca}_{\mathrm{V}} 2.2$ currents for $\mathrm{Ca}_{\mathrm{v}} 2.2 / \alpha_{2} \delta-2$ coexpressed with $\beta 2 \mathrm{a}-\Delta \mathrm{vHOOK}$ (left), lack of basal facilitation with $\beta 2 \mathrm{a}-\mathrm{GK}(226-442)$ (center), and basal facilitation with $\beta 2 \mathrm{a}-\mathrm{SH} 3(1-135)+\mathrm{GK}(226-442)$. Traces are shown for $40 \mathrm{~ms}$ depolarizations to $+10 \mathrm{mV}$ before and after a depolarizing prepulse to $+100 \mathrm{mV}$. b Basal facilitation $\left(P_{2} / P_{1}\right)$ ratio between +10 and $+30 \mathrm{mV}$ for $\mathrm{Ca}_{\mathrm{V}} 2.2 / \alpha_{2} \delta-2$ coexpressed with $\beta 2 \mathrm{a}-\Delta \mathrm{vHOOK}(n=$ 9 , black bars $), \beta 2 \mathrm{a}-\Delta \mathrm{vHOOK}+$ transducin $-\alpha(n=7$, gray bars $), \mathrm{C} 3,4 \mathrm{~S}-$ $\beta 2 \mathrm{a}-\Delta \mathrm{vHOOK}(n=11$, hatched bars $), \beta 2 \mathrm{a}-\mathrm{SH} 3(1-135)+\mathrm{GK}(226-$ 442) ( $n=9$, horizontal striped bars), and $\beta 2 \mathrm{a}-\mathrm{GK}(226-442)(n=10$,

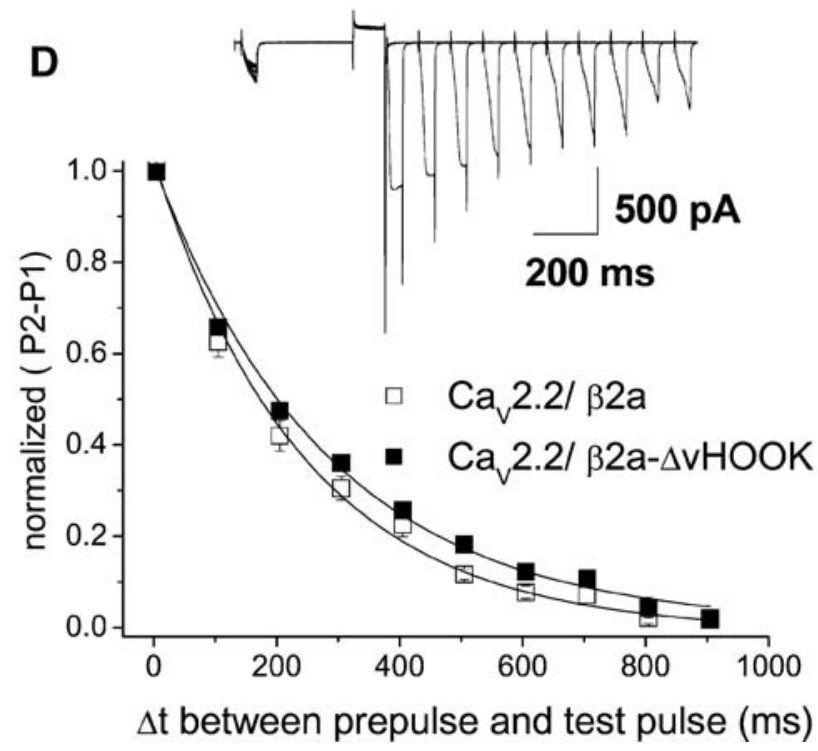

dashed bars, repeated from Fig. $3 \mathrm{~d}$ for comparison). The dotted line indicates a $P_{2} / P_{1}$ ratio of 1 , i.e., no basal facilitation. $\mathbf{c}$ Time course of facilitation with increasing prepulse duration $\Delta t$ for $\beta 2$ a (open squares, $n=10$ ), $\beta 2 \mathrm{a}-\Delta \mathrm{vHOOK}$ (filled squares, $n=10$ ), and $\beta 2 \mathrm{a}-$ SH3 (1-135) and GK (226-442) (open stars, $n=9)$. The lines are single exponential fits to the mean data. $\mathbf{d}$ Time course of reinhibition with increasing duration $\Delta t$ between prepulse and $P_{2}$ test pulse for $\beta 2 \mathrm{a}$ (open squares, $n=6$ ) and $\beta 2 \mathrm{a}-\Delta \mathrm{vHOOK}$ (filled squares, $n=6$ ). The lines are single exponential fits to the mean data. The inset shows an example set of traces showing the increasing inhibition of the $P_{2}$ traces with increased $\Delta t$ 
much higher at $+120 \mathrm{mV}$ than that estimated at $-100 \mathrm{mV}$, nevertheless, the off-rate of $\mathrm{G} \beta \gamma$ from the $\beta 2 \mathrm{a}-\Delta \mathrm{vHOOK}$ construct was slower than that for the wild-type $\beta 2 \mathrm{a}$ at both potentials.

To examine further whether the presence of the SH3 domain played any role in $\mathrm{G}$ protein modulation, we finally examined the effect of including the SH3 and GK domains as two separate constructs. We found previously that the $\beta 2 \mathrm{a}-$ SH3 (1-135) domain, which retains a palmitoylation site and can, therefore, accumulate in the vicinity of the plasma membrane, is able to interact with $\beta 2 \mathrm{a}-\mathrm{GK}(136-442)$ and mimic full-length $\beta 2 \mathrm{a}$ in its biophysical properties [32]. In contrast, $\beta 2 \mathrm{a}-\mathrm{SH} 3(1-135)$ did not show any interaction with the isolated $\beta 2 \mathrm{a}-\mathrm{GK}(226-442)$, which is lacking the final ( $\varepsilon) \beta$-strand of the SH3 domain that is required for the interaction, but did show interaction with $\beta 2 \mathrm{a}-\mathrm{GK}$ (214442), which is lacking only the variable HOOK region, but retains the $\varepsilon$-strand that completes the $\mathrm{SH} 3$ domain [32]. These results are confirmed by our yeast two-hybrid results (see Fig. 6).

The effect of including together the noninteracting pair of constructs $\beta 2 \mathrm{a}-\mathrm{SH} 3$ (1-135) and $\beta 2 \mathrm{a}-\mathrm{GK}(226-442)$ on the basic current properties was a reduction, rather than an increase, in the peak $I_{\mathrm{Ba}}$ compared to $\beta 2 \mathrm{a}-\mathrm{GK}(226-442)$ alone (Table 1) and a depolarization of the voltage for $50 \%$ activation of the current to $+24.9 \pm 2.4 \mathrm{mV}(n=5)$ compared to $+32.0 \pm 3.6(n=$ 7) for $\beta 2 a-G K ~(226-442)$ alone. As a possible explanation and in confirmation of the results described above for $\beta 2 \mathrm{a}-$ $\Delta \mathrm{vHOOK}$, we found that the inclusion of $\beta 2 \mathrm{a}-\mathrm{SH} 3(1-135)$ with $\beta 2 a-G K(226-442)$ resulted in calcium channel currents that showed strong tonic modulation. In the absence of agonist, the peak $I_{\mathrm{Ba}}$ showed a basal facilitation of $2.61 \pm 0.72$ at $+10 \mathrm{mV}$ (Fig. 5a,b), which is likely to be the reason that the peak $I_{\mathrm{Ba}}$ was smaller in the presence than in the absence of ß2a-SH3 (1-135) (Table 1). This is in strong contrast to the lack of facilitation shown by either of the $\beta 2 \mathrm{a}-\mathrm{GK}$ domains alone (Figs. $3 \mathrm{~d}$ and $5 \mathrm{~b}$ ). For this pair of constructs, the time constant for the removal of tonic inhibition $\left(\tau_{\text {dissoc }}\right)$ at $+120 \mathrm{mV}$ was $29.1 \pm 5.4 \mathrm{~ms}$ (Fig. 5c, $P>0.05$ compared to $\beta 2 \mathrm{a}$ ).

Yeast two-hybrid assays were performed in order to probe any direct interactions between the $\mathrm{Ca}_{\mathrm{V}} \beta$ subunit constructs and the I-II linker of $\mathrm{Ca}_{\mathrm{V}} 2.2$ and whether the interactions between specific $\beta$ subunit domains matched the results obtained in our electrophysiological experiments (Fig. 6). Our positive control was the interaction between the $\mathrm{Ca}_{\mathrm{v}} 2.2$ I-II linker and full-length $\beta 1 \mathrm{~b}$ (Fig. 6a, column 1), which has been demonstrated by many different techniques, including surface plasmon resonance $[9,11,21]$. We found a $\beta 2$ a construct missing the extreme $\mathrm{N}$ terminus and the $\mathrm{C}$ terminus (5-442) also interacted with the I-II linker (Fig. 6a, column 2). The truncated constructs $\beta 2 \mathrm{a}-\varepsilon \mathrm{SH} 3+\mathrm{GK}(214$ $442)$ and $\beta 2 \mathrm{a}-\mathrm{HOOK}+\varepsilon \mathrm{SH} 3+\mathrm{GK}(135-442)$ also interacted with the I-II linker (Fig. 6a, columns 3 and 4), whereas the
A
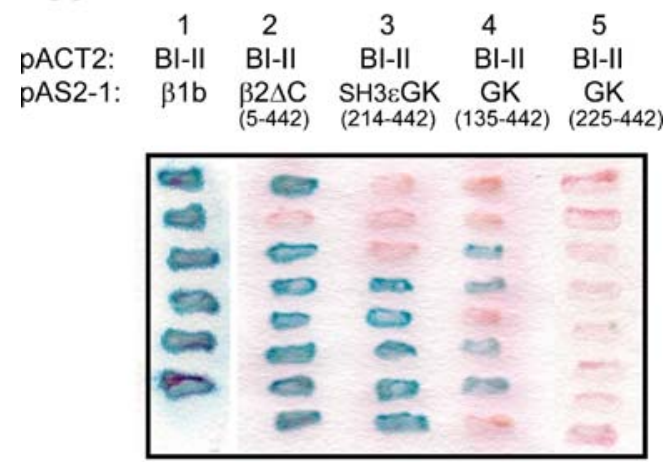

B

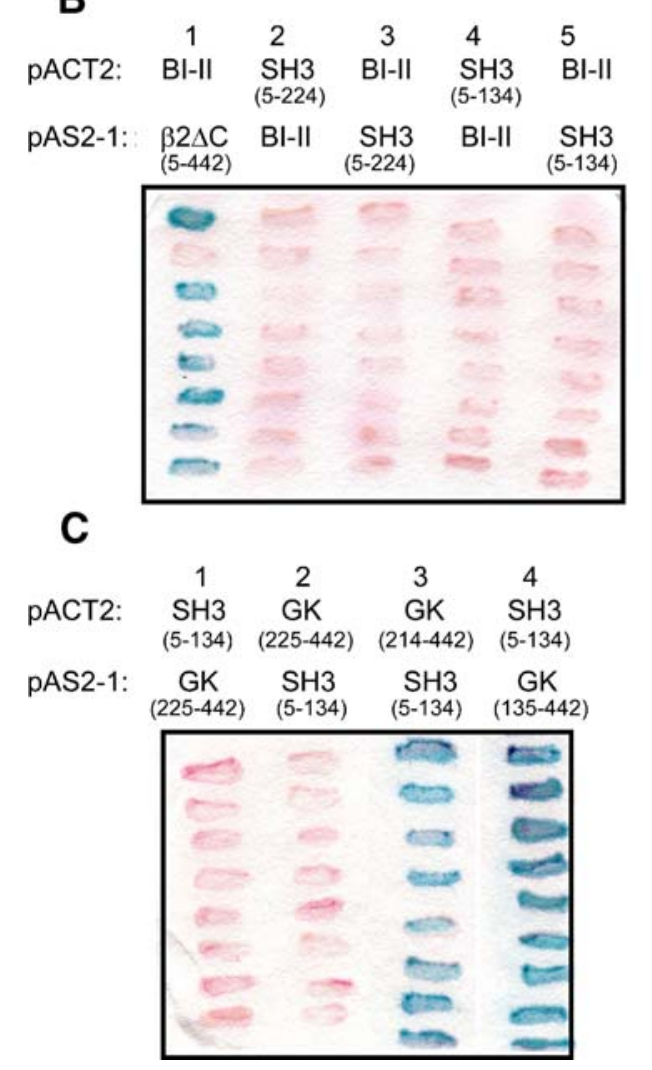

Fig. 6 Protein interactions involving $\beta 2 \mathrm{a}$ domains. Protein interactions were demonstrated using $\beta$-galactosidase assays after cotransformation of plasmids into yeast. Blue colonies indicate a positive interaction. a Positive control showing $\mathrm{Ca}_{\mathrm{V}} 2.2 \mathrm{I}-\mathrm{II}$ loop (BI-II) pACT2 and $\beta 1 \mathrm{~b}$ pAS2-1 (lane 1). $\beta 2 \mathrm{a}$ minus the $\mathrm{C}$ terminus (5-442), $\beta 2 \mathrm{a}-\varepsilon S H 3+\mathrm{GK}$ (214 442), and $\beta 2 \mathrm{a}-\mathrm{HOOK}+\varepsilon \mathrm{SH} 3+\mathrm{GK}(135-442)$ interacted with the I-II linker (lanes 2-4) whereas $\beta 2 \mathrm{a}-\mathrm{GK}$ (225-442) showed no interaction (lane 5). b Positive control showing $\beta 2 \mathrm{a}$ minus the $\mathrm{C}$ terminus (5-442) interacting with BI-II (lane 1). No interactions were demonstrated between SH3 domains and BI-II (lanes 2-5). c The shortest GK construct (225-442) was not found to interact with $\beta 2 \mathrm{a}$ SH3 (5-134) (lanes 1 and 2) whereas the longer GK constructs, $\beta 2 \mathrm{a}-$ $\varepsilon S H 3+G K(214-442)$ and $\beta 2 \mathrm{a}-\mathrm{HOOK}+\varepsilon S H 3+\mathrm{GK}(135-442)$, showed a positive interaction (lanes 3 and 4 )

shortest construct $\beta 2 \mathrm{a}-\mathrm{GK}$ domain $(225-442)$ did not interact with the I-II linker in this assay (Fig. 6a, column $5)$. Furthermore, none of the $\beta 2 \mathrm{a}-\mathrm{SH} 3$ domains tested interacted with the I-II of $\mathrm{Ca}_{\mathrm{V}} 2.2$ (Fig. 6b). These included 
32a-SH3+HOOK (5-224) (Fig. 6b, columns 2 and 3) and $\beta 2 \mathrm{a}-\mathrm{SH} 3$ (5-134) (Fig. 6b, columns 4 and 5).

We also found that $\beta 2 a-S H 3$ (5-134) did not interact with $32 \mathrm{a}-\mathrm{GK}(225-442)$ (Fig. 6c, columns 1 and 2 with the constructs in either vector), whereas it showed strong interactions with $\beta 2 a-\varepsilon S H 3+G K(214-442)$ (Fig. 6c, column 3) and with $\beta 2 \mathrm{a}-\mathrm{HOOK}+\varepsilon \mathrm{SH} 3+\mathrm{GK}(135-442)$ (Fig. 6c, column 4).

\section{Discussion}

The core structure of all $\mathrm{Ca}_{\mathrm{V}} \beta$ subunits is characterized by a GK and an SH3 domain [13, 18, 27, 39]. The 18-amino-acid AID motif in the I-II loop of HVA $\mathrm{Ca}_{\mathrm{V}} \alpha_{1}$ subunits is crucial for binding to $\mathrm{Ca}_{\mathrm{V}} \beta$ subunits $[4,21,29]$. Recent structural data from three groups have provided detailed information about $\mathrm{Ca}_{\mathrm{V}} \beta$ subunits and their interaction with the AID sequence [13, 27, 39]. However, the structural studies provided no insight into the role of the disordered HOOK domain, which intervenes in the split SH3 domain, before its fifth $\beta$-strand. In this study, we have examined which $\mathrm{Cav}_{\mathrm{V}} \beta$ subunit domains are involved in promoting the voltage dependence of $\mathrm{G}$ protein modulation, which is lost in the absence of any $\mathrm{Ca}_{\mathrm{V}} \beta$ subunit $[9,21]$.

Requirement of $\mathrm{Ca}_{\mathrm{V}} \beta$ GK domains for plasma membrane expression of HVA calcium channels

One of the main effects of $C a_{V} \beta$ subunits on HVA calcium channels is to increase current density. However, the mechanism for this increase remains controversial, either being attributed to increased trafficking [6], increased maximum open probability [26], or both. In agreement with the first hypothesis, we and others have shown biochemically that the proportion of $\mathrm{HVA} \mathrm{Ca}_{\mathrm{V}} \alpha 1$ subunits in the plasma membrane is increased by $\mathrm{Ca}_{\mathrm{V}} \beta$ subunit coexpression $[1,9,14,21]$. This finding was reinforced by the fact that fewer channels were present at the surface when the mutated $\mathrm{Ca}_{\mathrm{V}} 2.2 \mathrm{~W} 391 \mathrm{~A}$ channels that did not interact with $\beta$ subunits were cotransfected with a $\mathrm{Ca}_{V} \beta$ [21]. However, it is clear that $\mathrm{Ca}_{\mathrm{V}} \beta$ subunits also increase the open probability for $\mathrm{Ca}_{\mathrm{V}} 2.2$ as well as other HVA channels [20, 25].

The $\mathrm{Ca}_{\mathrm{V}} \beta$ GK domain is sufficient to restore voltage-dependent $\mathrm{G}$ protein modulation of $\mathrm{Ca}_{\mathrm{V}} 2.2$ channels

We showed previously that abrogation of the interaction of $\mathrm{Ca}_{\mathrm{V}} 2.2$ with a $\mathrm{Ca}_{\mathrm{V}} \beta$ subunit, by introduction of the W391A mutation in the AID motif, did not affect the ability of $G \beta \gamma$ to inhibit $\mathrm{Ca}_{\mathrm{V}} 2.2$, but did prevent the removal of $\mathrm{G} \beta \gamma$ by a depolarizing prepulse [21]. In this study, we have obtained similar results when $\mathrm{Ca}_{\mathrm{V}} 2.2$ was expressed without any
$\mathrm{Ca}_{\mathrm{V}} \beta$ subunit and we found that coexpression of GK domain constructs from either $\beta 2 \mathrm{a}$ or $\beta 1 \mathrm{~b}$ is sufficient to restore the voltage dependence of $G$ protein modulation to wild-type $\mathrm{Ca}_{\mathrm{v}} 2.2$ channels.

It has been found in several studies $[3,15]$ that the $G \beta \gamma$ subunits, which are responsible for direct $G$ protein modulation of calcium channels, bind to the AID region of the I-II linker, and it has been proposed that they may compete with $\mathrm{Ca}_{\mathrm{V}} \beta$ subunits [33]. In contrast, fluorescence resonance energy transfer (FRET) studies have shown that $\mathrm{Ca}_{\mathrm{V}} \beta$ and $\mathrm{G} \beta \gamma$ are able to bind to calcium channels at the same time [19]. Also in disagreement with a simple competition between $G \beta \gamma$ and $C_{V} \beta$ subunits is the finding that the presence of $\mathrm{Ca}_{\mathrm{V}} \beta$ subunits does not reduce the amount of $\mathrm{G}$ protein modulation $[10,24]$. However, we did find that the presence of $\mathrm{Ca}_{\mathrm{V}} \beta$ subunits promoted the voltage-dependent removal of $\mathrm{G} \beta \gamma$ by depolarizing prepulses [10, 24]. A similar conclusion was reached by using $\mathrm{Ca}_{\mathrm{V}} 2.2$ containing the W391A mutation in the I-II linker, such that it did not interact with $\mathrm{Ca}_{\mathrm{V}} \beta$ subunits [21].

Involvement of other $\beta$ subunit domains in $\mathrm{G}$ protein modulation of calcium channels

The results described in this study and our previous study [32] indicate that the reduced $\mathrm{G}$ protein modulation of the palmitoylatable compared to the nonpalmitoylatable $\beta 2$ constructs is likely to be related to the fact that palmitoylation maintains an elevated concentration of this $\mathrm{Ca}_{\mathrm{V}} \beta$ subunit associated with the inner leaflet of the plasma membrane and, therefore, in the vicinity of the channel. However, as we and others have discussed previously [24], there is unlikely to be a simple competition between $\mathrm{G} \beta \gamma$ and $\mathrm{Ca}_{\mathrm{V}} \beta$ subunits for binding to the I-II linker. Furthermore, in this study, we found that there is little difference in the amount of $G$ protein modulation in the absence compared to the presence of any of the free GK domains. These findings indicate that the reduced $G$ protein modulation seen with $\beta 2 a$ is unlikely to be due solely to the fact that its palmitoylation results in an increased occupancy by its GK domain of the I-II linker. Moreover, the results with the HOOK deletion constructs indicate that the proposed interaction of the HOOK domain of $\beta 2 \mathrm{a}$ with the channel is also not responsible alone for the reduced modulation observed with palmitoylated $\beta 2 \mathrm{a}$. This suggests that the increased interaction of both the SH3 domain and the HOOK domain with the channel, resulting from palmitoylation of $\beta 2 a$, is responsible for this difference in extent of $\mathrm{G}$ protein modulation.

Determinants of tonic modulation of $\mathrm{Ca}_{\mathrm{v}} 2.2$

The strong basal facilitation of the $\beta 2 \mathrm{a}$ construct lacking the variable part of the HOOK domain requires its palmitoylation 
and indicates that the absence of this HOOK domain of $\beta 2 \mathrm{a}$ promotes, either directly or indirectly, tonic $\mathrm{G} \beta \gamma$ binding. It is also possible that removal of the variable HOOK domain constrains the structure of the $\mathrm{Ca}_{\mathrm{V}} \beta$ subunit and that other parts of the calcium channel are also involved in $G \beta \gamma$ binding. In support of this, we noted a trend to increased basal facilitation for GK (136-442), containing the HOOK domain, compared to GK (226-442) in which the HOOK domain was absent, although this did not reach statistical significance.

The results from the experiment utilizing the combination of $\beta 2 \mathrm{a}-\mathrm{SH} 3(1-135)$ and $\beta 2-\mathrm{GK}(226-442)$ lacking the HOOK domain confirm the results obtained with $\beta 2 \mathrm{a}-\Delta \mathrm{vHOOK}$, since both show strong tonic modulation. We interpret these results as indicating that the presence of the palmitoylatable free $\mathrm{SH} 3$ domain, in the absence of the variable part of the HOOK domain of $\beta 2 \mathrm{a}$, promotes basal facilitation of $\mathrm{Ca}_{\mathrm{v}} 2.2$ channels and results in increased tonic $\mathrm{G} \beta \gamma$ binding. Our previous evidence [32] indicates that $\beta 2 \mathrm{a}-\mathrm{SH} 3$ (1-135) is palmitoylated, since when it is coexpressed with GK(136-442), it reconstitutes the properties of palmitoylated $\beta 2 \mathrm{a}$, in terms of slow inactivation, an effect which has been attributed to palmitoylation [21, 30]. Our present results further indicate that an interaction between the GK domain and the SH3 domain of $\beta 2 \mathrm{a}$ is not necessary for the demonstration of tonic G protein modulation, since $\beta 2 \mathrm{a}-\mathrm{SH} 3(1-135)+\beta 2-\mathrm{GK}$ (226$442)$ and $\beta 2 a-\Delta v H O O K$ showed quite similar properties with respect to expression of tonic facilitation.

Although our electrophysiological data indicate that additional interactions are likely to occur between the $\mathrm{Ca}_{\mathrm{V}} 2.2$ channels and both the SH3 and the HOOK domains of $\mathrm{Ca}_{\mathrm{V}} \beta$ subunits, nevertheless, our yeast two-hybrid data do not indicate that there is an interaction between the $\beta 2 \mathrm{a}-$ SH3 domain and the I-II linker of $\mathrm{Ca}_{\mathrm{V}} 2.2$, in contrast to a previous study using $\mathrm{Ca}_{\mathrm{V}} 2.1$ [23]. This was also suggested previously from our binding results for $\beta 1 \mathrm{~b}$, since it showed the same binding affinity for the full-length $\mathrm{Ca}_{\mathrm{V}} 2.2 \mathrm{I}-\mathrm{II}$ linker as the I-II linker truncated just after the AID region, indicating that there are no additional binding sites for the $\beta$ subunit distal to the AID motif $[9,21]$.

In the present study, we have not addressed the other regions of the $\mathrm{Ca}_{\mathrm{V}} 2.2$ subunit involved in this interaction, but other studies have shown that $\mathrm{G} \beta \gamma$ binds to the $\mathrm{C}$ terminus of $\mathrm{Ca}_{\mathrm{V}} 2.2$ [22] and that the I-II linker itself interacts with other regions of $\mathrm{Ca}_{\mathrm{V}} 2$ channels [36]. These results, among others, indicate that $\mathrm{G} \beta \gamma$ is likely to bind to a complex statedependent binding pocket, also including the $\mathrm{N}$ terminus of the channel [28].

Our electrophysiological data suggest that the presence of the HOOK domain is important for the voltage-dependent removal of $\mathrm{G} \beta \gamma$. In particular, we calculate that in the absence of the HOOK domain, the affinity of the $\mathrm{Ca}_{\mathrm{V}} 2.2 / \mathrm{Ca}_{\mathrm{V}} \beta 2$ complex for $\mathrm{G} \beta \gamma$ is increased about threefold. The effect of this change in affinity is manifested particularly at resting
$\mathrm{G} \beta \gamma$ levels, previously estimated to be about $50 \mathrm{nM}$ [34], when it leads to substantial tonic $\mathrm{G} \beta \gamma$ modulation. It is also evidenced by a more rapid rate of rebinding of $G \beta \gamma$, following its removal by a depolarizing prepulse. These findings are in agreement with the hypothesis proposed previously $[9,11,21]$ that the greater the occupancy of the binding site for $\mathrm{Ca}_{\mathrm{V}} \beta$ subunit on the channel, the greater is the voltage dependence of $\mathrm{G}$ protein inhibition.

In our previous study [32], we provided evidence that the HOOK domain of $\beta 2 \mathrm{a}$ is involved in modulating voltagedependent inactivation, since removal of the HOOK domain shifted the steady-state inactivation to more negative potentials and also increased the inactivation kinetics. The contribution of inactivation imposed by different $\mathrm{Ca}_{\mathrm{V}} \beta$ subunits on $\mathrm{G}$ protein regulation has been investigated previously $[25$, 41]. We found that the inactivation properties of expressed $\mathrm{Ca}_{\mathrm{V}} 2.2$ channels depended on the $\mathrm{Ca}_{\mathrm{V}} \beta$ subunit species, but only to a minor extent on the presence or absence of $G \beta \gamma$. Furthermore, the closed times and latency to first opening of the $\mathrm{Ca}_{\mathrm{v}} 2.2$ channels were increased by $\mathrm{G} \beta \gamma$, but this effect was similar for both $\beta 1 b$ and $\beta 2 a$ subunits [25]. More recently, the effect of the inactivation on $G$ protein modulation was studied, and an effect was observed on voltagedependent recovery from $G$ protein modulation because of the opposing effects of different $\mathrm{Ca}_{\mathrm{V}} \beta$ subunits on inactivation [41]. In this study, we show directly that removal of the $\beta 2 \mathrm{a}$ HOOK domain enhances $\mathrm{G} \beta \gamma$ binding affinity. In the future, this may help to identify how $\mathrm{G} \beta \gamma$ dimers modulate the $\mathrm{Ca}_{\mathrm{V}} 2$ channels.

\section{Conclusions}

The present results indicate that the interaction of a $\mathrm{Ca}_{\mathrm{V}} \beta$ subunit GK domain alone with the $\mathrm{Ca}_{\mathrm{v}} 2.2$ channel is sufficient to restore voltage dependence to the $\mathrm{G}$ protein modulation process. However, these results also suggest that the $\mathrm{SH} 3$ and HOOK domains of $\mathrm{Ca}_{\mathrm{V}} \beta$ subunits are likely to have a role in preventing tonic binding of $\mathrm{G} \beta \gamma$ to the calcium channels.

Acknowledgements This work was supported by The Wellcome Trust. We thank the following for the generous gifts of cDNAs: Dr. Y. Mori (Seriken, Okazaki, Japan) for the rabbit $\mathrm{Ca}_{\mathrm{V}} 2.2$; Dr. E. PerezReyes (Loyola University, Chicago, IL, USA) for the rat $\beta 2 \mathrm{a}$; Dr. R. T. Hughes (Yale, New Haven, CT, USA) for the mut-3 GFP; Genetics Institute (Cambridge, MA, USA) for the pMT2. We also thank K. Chaggar for the technical assistance and Selvan Bavan for performing some of the molecular biology.

\section{Conflict of interests None.}

Open Access This article is distributed under the terms of the Creative Commons Attribution Noncommercial License which permits any noncommercial use, distribution, and reproduction in any medium, provided the original author(s) and source are credited. 


\section{References}

1. Altier C, Dubel SJ, Barrère C, Jarvis SE, Stotz SC, Spaetgens RL, Scott JD, Cornet V, De Waard M, Zamponi GW, Nargeot J, Bourinet E (2002) Trafficking of L-type calcium channels mediated by the postsynaptic scaffolding protein AKAP79. J Biol Chem 277:33598-33603

2. Barclay J, Balaguero N, Mione M, Ackerman SL, Letts VA, Brodbeck J, Canti C, Meir A, Page KM, Kusumi K, PerezReyes E, Lander ES, Frankel WN, Gardiner RM, Dolphin AC, Rees M (2001) Ducky mouse phenotype of epilepsy and ataxia is associated with mutations in the Cacna2d2 gene and decreased calcium channel current in cerebellar Purkinje cells. J Neurosci 21:6095-6104

3. Bell DC, Butcher AJ, Berrow NS, Page KM, Brust PF, Nesterova A, Stauderman KA, Seabrook GR, Nurnberg B, Dolphin AC (2001) Biophysical properties, pharmacology and modulation of human, neuronal L-type (a1D, $\mathrm{Ca}_{\mathrm{V}} 1.3$ ) voltage-dependent calcium currents. J Neurophysiol 85:816-828

4. Berrou L, Klein H, Bernatchez G, Parent L (2002) A specific tryptophan in the I-II linker is a key determinant of beta-subunit binding and modulation in $\mathrm{Ca}(\mathrm{V}) 2.3$ calcium channels. Biophys $\mathrm{J}$ 83:1429-1442

5. Bertaso F, Ward RJ, Viard P, Milligan G, Dolphin AC (2003) Mechanism of action of G(q) to inhibit gbetagamma modulation of $\mathrm{Ca}(\mathrm{V}) 2.2$ calcium channels: probed by the use of receptor-galpha tandems. Mol Pharmacol 63:832-843

6. Bichet D, Cornet V, Geib S, Carlier E, Volsen S, Hoshi T, Mori Y, De Waard M (2000) The I-II loop of the Ca2+ channel alpha(1) subunit contains an endoplasmic reticulum retention signal antagonized by the beta subunit. Neuron 25:177-190

7. Birnbaumer L, Qin N, Olcese R, Tarteilus E, Platano E, Costantin J, Stefani E (1998) Structures and functions of calcium channel b subunits. J Bioenerg Biomembranes 30:357-376

8. Brice NL, Berrow NS, Campbell V, Page KM, Brickley K, Tedder I, Dolphin AC (1997) Importance of the different $b$ subunits in the membrane expression of the a1A and a 2 calcium channel subunits: studies using a depolarisation-sensitive a1 A antibody. Eur J Neurosci 9:749-759

9. Butcher AJ, Leroy J, Richards MW, Pratt WS, Dolphin AC (2006) The importance of occupancy rather than affinity of $\mathrm{CaV}$ \{beta\} subunits for the calcium channel I-II linker in relation to calcium channel function. J Physiol 574:387-398

10. Canti C, Bogdanov Y, Dolphin AC (2000) Interaction between G proteins and accessory $\mathrm{b}$ subunits in the regulation of a1B calcium channels in Xenopus oocytes. J Physiol 527:419-432

11. Canti C, Davies A, Berrow NS, Butcher AJ, Page KM, Dolphin AC (2001) Evidence for two concentration-dependent processes for $\mathrm{b}$ subunit effects on a1B calcium channels. Biophys $\mathrm{J} 81$ : 1439-1451

12. Catterall WA (2000) Structure and regulation of voltage-gated $\mathrm{Ca}^{2+}$ channels. Annu Rev Cell Dev Biol 16:521-555

13. Chen YH, Li MH, Zhang Y, He LL, Yamada Y, Fitzmaurice A, Shen Y, Zhang H, Tong L, Yang J (2004) Structural basis of the alpha1beta subunit interaction of voltage-gated $\mathrm{Ca} 2+$ channels. Nature 429:675-680

14. Cohen RM, Foell JD, Balijepalli RC, Shah V, Hell JW, Kamp TJ (2005) Unique modulation of L-type Ca2+ channels by short auxiliary betald subunit present in cardiac muscle. Am J Physiol Heart Circ Physiol 288:H2363-H2374

15. De Waard M, Liu HY, Walker D, Scott VES, Gurnett CA, Campbell KP (1997) Direct binding of G-protein bgamma complex to voltagedependent calcium channels. Nature 385:446-450

16. Dolphin AC (2003) b subunits of voltage-gated calcium channels. J Bioenerg Biomembranes 35:599-620

17. Ertel EA, Campbell KP, Harpold MM, Hofmann F, Mori Y, PerezReyes E, Schwartz A, Snutch TP, Tanabe T, Birnbaumer L, Tsien
RW, Catterall WA (2000) Nomenclature of voltage-gated calcium channels. Neuron 25:533-535

18. Hanlon MR, Berrow NS, Dolphin AC, Wallace BA (1999) Modelling of a voltage-dependent $\mathrm{Ca}^{2}+$ channel $b$ subunit as a basis for understanding its functional properties. FEBS Lett 445:366-370

19. Hummer A, Delzeith O, Gomez SR, Moreno RL, Mark MD, Herlitze S (2003) Competitive and synergistic interactions of $G$ protein beta (2) and $\mathrm{Ca}(2+)$ channel beta(1b) subunits with $\mathrm{Ca}(\mathrm{v}) 2.1$ channels, revealed by mammalian two-hybrid and fluorescence resonance energy transfer measurements. J Biol Chem 278:49386-49400

20. Jones LP, Wei SK, Yue DT (1998) Mechanism of auxiliary subunit modulation of neuronal $\mathrm{a}_{1 \mathrm{E}}$ calcium channels. J Gen Physiol 112:125-143

21. Leroy J, Richards MS, Butcher AJ, Nieto-Rostro M, Pratt WS, Davies A, Dolphin AC (2005) Interaction via a key tryptophan in the I-II linker of N-type calcium channels is required for betal but not for palmitoylated beta2, implicating an additional binding site in the regulation of channel voltage-dependent properties. J Neurosci 25:6984-6996

22. Li B, Zhong H, Scheuer T, Catterall WA (2004) Functional role of a C-terminal Gbetagamma-binding domain of $\mathrm{Ca}(\mathrm{v}) 2.2$ channels. Mol Pharmacol 66:761-769

23. Maltez JM, Nunziato DA, Kim J, Pitt GS (2005) Essential Ca(v) beta modulatory properties are AID-independent. Nat Struct Mol Biol 12:372-377

24. Meir A, Bell DC, Stephens GJ, Page KM, Dolphin AC (2000) Calcium channel $\mathrm{b}$ subunit promotes voltage-dependent modulation of a1B by Gbg. Biophys J 79:731-746

25. Meir A Dolphin AC (2002) Kinetics and Gbetagamma modulation of $\mathrm{Ca}(\mathrm{v}) 2.2$ channels with different auxiliary beta subunits. Pflugers Arch 444:263-275

26. Neely A, Garcia-Olivares J, Voswinkel S, Horstkott H, Hidalgo P (2004) Folding of active calcium channel beta(1b)-subunit by sizeexclusion chromatography and its role on channel function. J Biol Chem 279:21689-21694

27. Opatowsky Y, Chen CC, Campbell KP, Hirsch JA (2004) Structural analysis of the voltage-dependent calcium channel beta subunit functional core and its complex with the alphal interaction domain. Neuron 42:387-399

28. Page KM, Canti C, Stephens GJ, Berrow NS, Dolphin AC (1998) Identification of the amino terminus of neuronal $\mathrm{Ca}^{2+}$ channel a1 subunits a1B and a1E as an essential determinant of $\mathrm{G}$ protein modulation. J Neurosci 18:4815-4824

29. Pragnell M, De Waard M, Mori Y, Tanabe T, Snutch TP, Campbell KP (1994) Calcium channel b-subunit binds to a conserved motif in the I-II cytoplasmic linker of the $\mathrm{a}_{1}$-subunit. Nature 368:67-70

30. Qin N, Platano D, Olcese R, Costantin JL, Stefani E, Birnbaumer L (1998) Unique regulatory properties of the type $2 \mathrm{a} \mathrm{Ca}^{2+}$ channel b subunit caused by palmitoylation. Proc Natl Acad Sci U S A 95:4690-4695

31. Richards MW, Butcher AJ, Dolphin AC (2004) Calcium channel beta-subunits: structural insights AID our understanding. Trends Pharmacol Sci 25:626-632

32. Richards MW, Leroy J, Pratt WS, Dolphin AC (2007) The HOOKDomain Between the SH3 and the GK Domains of CaVbeta subunits contains key determinants controlling calcium channel inactivation. Channels 1:92-101

33. Sandoz G, Lopez-Gonzalez I, Grunwald D, Bichet D, Altafaj X, Weiss N, Ronjat M, Dupuis A, De Waard M (2004) Cavbeta-subunit displacement is a key step to induce the reluctant state of $\mathrm{P} / \mathrm{Q}$ calcium channels by direct $\mathrm{G}$ protein regulation. Proc Natl Acad Sci U S A 101:6267-6272

34. Stephens GJ, Brice NL, Berrow NS, Dolphin AC (1998) Facilitation of rabbit a1B calcium channels: involvement of endogenous Gbgamma subunits. J Physiol (Lond) 509:15-27

35. Stephens GJ, Page KM, Bogdanov Y, Dolphin AC (2000) The a1B calcium channel amino terminus contributes determinants for $\mathrm{b}$ sub- 
unit mediated voltage-dependent inactivation properties. J Physiol (Lond) 525:377-390

36. Stotz SC, Hamid J, Spaetgens RL, Jarvis SE, Zamponi GW (2000) Fast inactivation of voltage-dependent calcium channels - a hingedlid mechanism? J Biol Chem 275:24575-24582

37. Takahashi SX, Miriyala J, Colecraft HM (2004) Membraneassociated guanylate kinase-like properties of beta-subunits required for modulation of voltage-dependent $\mathrm{Ca} 2+$ channels. Proc Natl Acad Sci U S A 101:7193-7198

38. Takahashi SX, Miriyala J, Tay LH, Yue DT, Colecraft HM (2005) A CaVbeta $\mathrm{SH} 3 /$ guanylate kinase domain interaction regulates multiple properties of voltage-gated $\mathrm{Ca} 2+$ channels. J Gen Physiol 126:365-377

39. Van Petegem F, Clark KA, Chatelain FC, Minor DL Jr (2004) Structure of a complex between a voltage-gated calcium channel beta-subunit and an alpha-subunit domain. Nature 429:671-675

40. Walker D, Bichet D, Campbell KP, De Waard M (1998) A b 4 isoformspecific interaction site in the carboxyl-terminal region of the voltagedependent $\mathrm{Ca}^{2+}$ channel $\mathrm{a}_{1 \mathrm{~A}}$ subunit. J Biol Chem 273:2361-2367

41. Weiss N, Tadmouri A, Mikati M, Ronjat M, De Waard M (2007) Importance of voltage-dependent inactivation in N-type calcium channel regulation by G-proteins. Pflugers Arch 454:115-129 